\title{
Siliceous microfossil succession in the recent history of two basins in Lake Baikal, Siberia
}

\author{
Mark B. Edlund ${ }^{1}$, E. F. Stoermer ${ }^{1}$ \& Cynthia H. Pilskaln ${ }^{2}$ \\ ${ }^{1}$ Center for Great Lakes and Aquatic Sciences, University of Michigan, 2200 Bonisteel Blvd., Ann Arbor, MI \\ 48109-2099, USA \\ ${ }^{2}$ Department of Oceanography, 5741 Libby Hall, Rm. 218, University of Maine, Orono, ME 04469-5741, USA
}

Received 15 November 1994; accepted 24 February 1995

Key words: Lake Baikal, Russia, paleolimnology, diatoms, chrysophyte cysts, Little Ice Age, climate change

\begin{abstract}
As part of the international cooperative Baikal Drilling Project, siliceous microfossil assemblage succession was analyzed in two short $(\sim 30-\mathrm{cm})$ sediment cores from Lake Baikal. One core was recovered from the north basin (Core $324,55^{\circ} 15^{\prime} \mathrm{N}, 109^{\circ} 30^{\prime} \mathrm{E}$ ), a second from between the central and southern basins (Core $316,52^{\circ} 28^{\prime} \mathrm{N}$, $\left.106^{\circ} 5^{\prime} \mathrm{E}\right)$. The northern core had higher amounts of biogenic silica ( $40 \mathrm{~g} \mathrm{SiO}_{2}$ per $100 \mathrm{~g}$ dry weight sediment) compared to the southern core, and increased deposition in the more recent sediments. Weight percent biogenic silica was lower in the southern core, ranging from approximately $20-30 \mathrm{~g} \mathrm{SiO}_{2}$ per $100 \mathrm{~g}$ dry weight sediment throughout the entire core. Trends in absolute microfossil abundance mirror those of biogenic silica, with generally greater abundance in the northern core $\left(86-275 \times 10^{6}\right.$ microfossils $\mathrm{g}^{-1}$ dry sediment) compared to the southern core (94-163 $\times 10^{6}$ microfossils $\mathrm{g}^{-1}$ dry sediment).

Cluster analyses using relative abundance of the dominant diatom and chrysophyte taxa revealed four zones of microfossil succession in each core. Microfossil assemblage succession in the north basin may be reflecting shifts in nutrient supply and cycling driven by climatic changes. The most recent sediments in the northern basin (Zone 1, c. 1890's-1991 A.D.) were characterized by an increased abundance of Aulacoseira baicalensis and Aulacoseira 'spore'. Zone 3 (c. 1630's -1830 's A.D.) was dominated by the endemic Cyclotella spp. and reduced abundance of the Aulacoseira spp. Zone 3 corresponds approximately to the Little Ice Age, a cooler climatic period. The microfossil assemblages between Zones 1 and 3 (Zone 2, c. 1830's-1890's A.D.) and below Zone 3 (Zone 4, c. 830 's -1430 's A.D.) are similar to one another suggesting they represent transitional intervals between warm and cold periods. Southern basin sediments record similar changes in the endemic taxa. However, the increased abundance of non-endemic planktonic taxa (e.g. Stephanodiscus binderanus, Synedra acus, Cyclostephanos dubius) during two periods in recent history (post World War II and late 1700's) suggests evidence for anthropogenic induced changes in southern Lake Baikal.
\end{abstract}

\section{Introduction}

Lake Baikal is the largest $\left(23000 \mathrm{~km}^{3}\right)$, deepest, and perhaps the oldest lake on Earth. Beneath its greater than $1.6 \mathrm{~km}$ depth, lies over $7 \mathrm{~km}$ of sediment, preserving a 25 million year Neogene history. The lake's age, large size, and extremely high degree of organismal endemism has attracted much scientific interest (Kozhov, 1963) and Baikal's great depths and geographic locale produce unique limnological conditions
(Weiss et al., 1991; Shimaraev et al., 1993; Bradbury et al., 1994).

Lake Baikal represents a unique and immense natural resource for Russia. Unfortunately, urban and industrial development, especially surrounding the southern basin, have placed added burden on the Baikal system (Belt, 1992). Maatela et al. (1990) revealed impacts on Baikal's benthic environment near southern industrial localities from effluent loadings. Galazii (1991) summarized some recent findings surrounding 
environmental impacts on Baikal, ranging from local extirpations of endemics to biodiversity loss. Fortunately, there appears to be increased awareness at local, national, and global levels surrounding the future use, protection, and understanding of Lake Baikal.

One sign of this new awareness surrounding Lake Baikal has been the creation of a cooperative group of international scientists to form the Baikal Drilling Project. This interdisciplinary group was formed to study the immense Baikal sediment record, with goals of reconstructing the geological evolution of the Lake Baikal depression and resolving a detailed, quantitative Quaternary climatic record (Lake Baikal Paleoclimate Project Members, 1992; Kuzmin et al., 1993).

The $7.5 \mathrm{~km}$ Baikal sediment record is very suitable for paleoclimatic reconstruction. An apparently continuous sedimentary record has been deposited since the Miocene and glaciations in the basin have been limited to the surrounding mountain regions rather than scouring the lake bed (Peck et al., 1994). Baikal's high latitude location makes it sensitive to long term insolation patterns reflecting changes in the Earth's orbital parameters (Kuzmin et al., 1993) and more short-term continental climate changes resulting from seasonal patterns associated with the shifts in the dominant Siberian high and Asiatic low (Lydolph, 1977; Bradbury et al., 1994). Changes in climatic conditions have affected Lake Baikal's limnological patterns, particularly ice thickness and duration, mixing depth, nutrient loading and recirculation, which all subsequently affect the timing and levels of algal production.

Paleolimnological methods hold strong promise for resolving climatic changes in Baikal's past. Bradbury \& Dieterich-Rurup (1993) analyzed the varved sediment record in north temperate Elk Lake (Minnesota, USA) and reported 100 to 1000 year climatic patterns during the past 10400 years. Even recent climatic events, such as the Little Ice Age (c. 1450-1850 A.D.), possibly characterized by cooler conditions and late springs, were resolved using the diatom record.

Earlier paleolimnological studies on Baikal have identified dramatic changes in the diatom communities over time. Chernyaeva (1970) studied diatom remains in a transect of seven cores across Baikal's north basin. While high resolution sampling was not employed, Chernyaeva showed that, in addition to high benthic diversity and well preserved remains, past changes had occurred in just the upper meter of sediment. These changes ranged from extirpation of some taxa, to taxonomic shifts in quantitative abundance. Bradbury et al. (1994) compiled data from cores (up to $11 \mathrm{~m}$ deep) taken throughout the Baikal basin and demonstrated the utility of Baikal sediments for resolving climate change. One core (305) provided an especially detailed record of the post-glacial Holocene (15.0 $1.3 \mathrm{ka}$ ). Bradbury et al. (1994) suggested that shifts in taxonomic composition of the microfossil assemblage reflected climatic shifts between cold-dry and warmmoist periods, as well as changes in nutrient dynamics associated with loadings and circulation. Unfortunately, both of these previous studies (Chernyaeva, 1970; Bradbury et al, 1994) had poor resolution of nearsurface changes in sedimentary signals because of either wide sampling intervals or loss of surficial sediments during coring.

While earlier paleolimnologic studies have not focused specifically on anthropogenic effects, there have been changes noted in Lake Baikal's primary producer communities over the last 50 years (Bondarenko et al., 1993; Popovskaya, 1993; Flower, 1993) possibly associated with human impacts (Galazii, 1991). Changes include, most notably, a significant increase in pennate diatom contribution to the plankton by Nitzschia acicularis W. Sm. and Synedra acus Kütz. since the 1950's, a decrease in relative abundance of some endemic taxa (e.g. Cyclotella baicalensis Skv. and $C$. ornata (Skv.) Flower), and recent appearance of nonendemic taxa. Changes of this nature often indicate changes in nutrient loading and a potential for increased productivity (Stoermer et al., 1993). However, while there has been increased nutrient loading to Baikal (Galazii, 1991), correlations to productivity increases have been difficult to make. Overall, increased productivity has not occurred, at least not at levels resolvable from annual variation. The system's plankton response has been through increased numerical abundance, especially of the small-celled species (Popovskaya, 1993). Similar changes were also evident from a survey of surficial sediments in Lake Baikal (Stoermer et al., 1995). Increased abundance of nonendemic centric taxa and greater numbers of planktonic pennates characterized the southern basin. Northern basin surficial sediments, on the other hand, were still dominated by the endemic Aulacoseira and Cyclotella taxa.

Records of modern changes in Baikal phytoplankton assemblages are incomplete and difficult to interpret. Dramatic seasonal and, more importantly, annual differences in phytoplankton composition and abundance (Kozhov, 1963; Popovskaya, 1991) make interpretations and predictions of annual production difficult. However, the sedimentary record preserved in 
the Baikal basin can provide answers to questions concerning both the recent and long term history of changes in this basin. In this study, we report on recent $(<1100 \mathrm{yr})$ siliceous microfossil assemblage succession in two short $(\sim 30-\mathrm{cm})$ sediment cores from Lake Baikal. Specific objectives of this project were to analyze the extent of anthropogenic modification in recent history of two basins in Lake Baikal and to determine if any climatic signals were evident in recent sedimentation.

\section{Materials and methods}

Box cores were recovered from two sites in Lake Baikal during summer 1991 as part of the Baikal Drilling Project (Lake Baikal Paleoclimate Project Members, 1992). Core 324 is from Baikal's north basin $\left(55^{\circ} 15^{\prime} \mathrm{N}, 109^{\circ} 30^{\prime} \mathrm{E}\right)$ and Core 316 is from between the central and southern basins $\left(52^{\circ} 28^{\prime} \mathrm{N}, 106^{\circ} 05^{\prime} \mathrm{E}\right)$ west of the Selenga River delta (Fig. 1). Subsampled cores from each box were sectioned by extrusion in ten $0.5-\mathrm{cm}$ intervals from 0 to $5.0 \mathrm{~cm}$, and select $1.0-\mathrm{cm}$ intervals were taken at 6-7, 8-9, 14-15, 20-21, 2627, 28-29 (Core 324 only), and 32-33 cm (Core 316 only). Core sections were refrigerated for further processing.

Weight percent sedimentary biogenic silica was analyzed spectrophotometrically with the molybdate blue method (Pilskaln \& Paduan, 1992). Extraction methods using $\mathrm{Na}_{2} \mathrm{CO}_{3}$ were adapted from Leinen (1977), Eggimen et al. (1980) and Mortlock \& Froelich (1989).

For siliceous microfossil preparation, a split from each section was freeze-dried to reduce microfossil breakage inherent with air or heat drying. A weighed dry subsample, between 11 and $13 \mathrm{mg}$, was boiled for $30 \mathrm{~min}$ in $30 \% \mathrm{H}_{2} \mathrm{O}_{2}$ at $110{ }^{\circ} \mathrm{C}$. After boiling, $25 \mathrm{ml}$ of concentrated $\mathrm{HNO}_{3}$ was added to the peroxidesediment solution. This resulted in a vigorous exothermic reaction within $5 \mathrm{~min}$, after which the solution was further heated at $120^{\circ} \mathrm{C}$ for an hour. Byproducts of oxidation were removed with six rinses of distilled water, allowing a minimum of six hours of settling between rinses. The entire sample was then poured into Battarbee drying chambers (Battarbee, 1973), allowed to evaporate to dryness, and the four replicate coverslips mounted in Hyrax ${ }^{T M}$.

A minimum of five hundred microfossils were enumerated on a single transect on each of two replicate coverslips using brightfield oil immersion
Table 1. Diatom and chrysophyte taxa used in cluster analysis, Core 324. Taxa chosen were present in five or more sample intervals at $>1 \%$ relative abundance

Aulacoseira baicalensis (C. Meyer) Simonsen

Aulacoseira baicalensis fo. square-punctae

Aulacoseira baicalensis fo. compacta

Aulacoseira 'spore' (Stoermer et al., 1995)

Cyclotella baicalensis Skv.

Cyclotella ornata (Skv) Flower

Cyclotella minuta (Skv.) Antipova

Stephanodiscus inconspicuus Mak. et Pomazkina

benthic Fragilaria spp.

chrysophyte cysts $1,3,18,22,31,35$

optics (N.A.>1.32) capable of $1200 \times$ magnification. Diatoms were identified to the lowest taxonomic designation and fragments of diatoms mathematically reconstituted to whole valve units. Chrysophyte cyst morphotypes were given a numerical identifier when first encountered (e.g., Figs 28-33). Sponge spicules were rare but also counted. Raw counts were converted to absolute abundance and reported as diatom valves or microfossils per $\mathrm{g}$ dry sediment. Counts were also converted to percent abundance and reported relative to total microfossil abundance.

To analyze the relationships among microfossil assemblages within the two cores, cluster analyses were performed on the most abundant taxa (Stoermer et al., 1985a), defined as those found in core sections with five occurrences at $>1 \%$ relative abundance (Tables $1 \& 2$ ). Discussion of the sedimentary distribution of taxa will be limited to these species. Cluster analyses were run with SYSTAT (Wilkinson, 1989) and were based on Euclidean distance measure and average distance clustering (Carney, 1982).

The limited subsample size available for our analyses precluded any dating estimates to be made directly on material from box cores 316 and 324 . In lieu of direct measurements, we estimated dates for each core using linear sedimentation rates calculated by Edgington et al. (1991). Edgington et al. (1991) collected short cores from throughout the Baikal basin in 1988, analyzed ${ }^{210} \mathrm{~Pb}$ and ${ }^{137} \mathrm{Cs}$ inventories, and calculated linear and mass sedimentation rates in each of Baikal's three basins and near the Selenga River delta. Two of the Edgington et al. (1991) stations (3 and 4) were near our Core 316 site and their two cores had mean sedimentation rates (including both with and without 


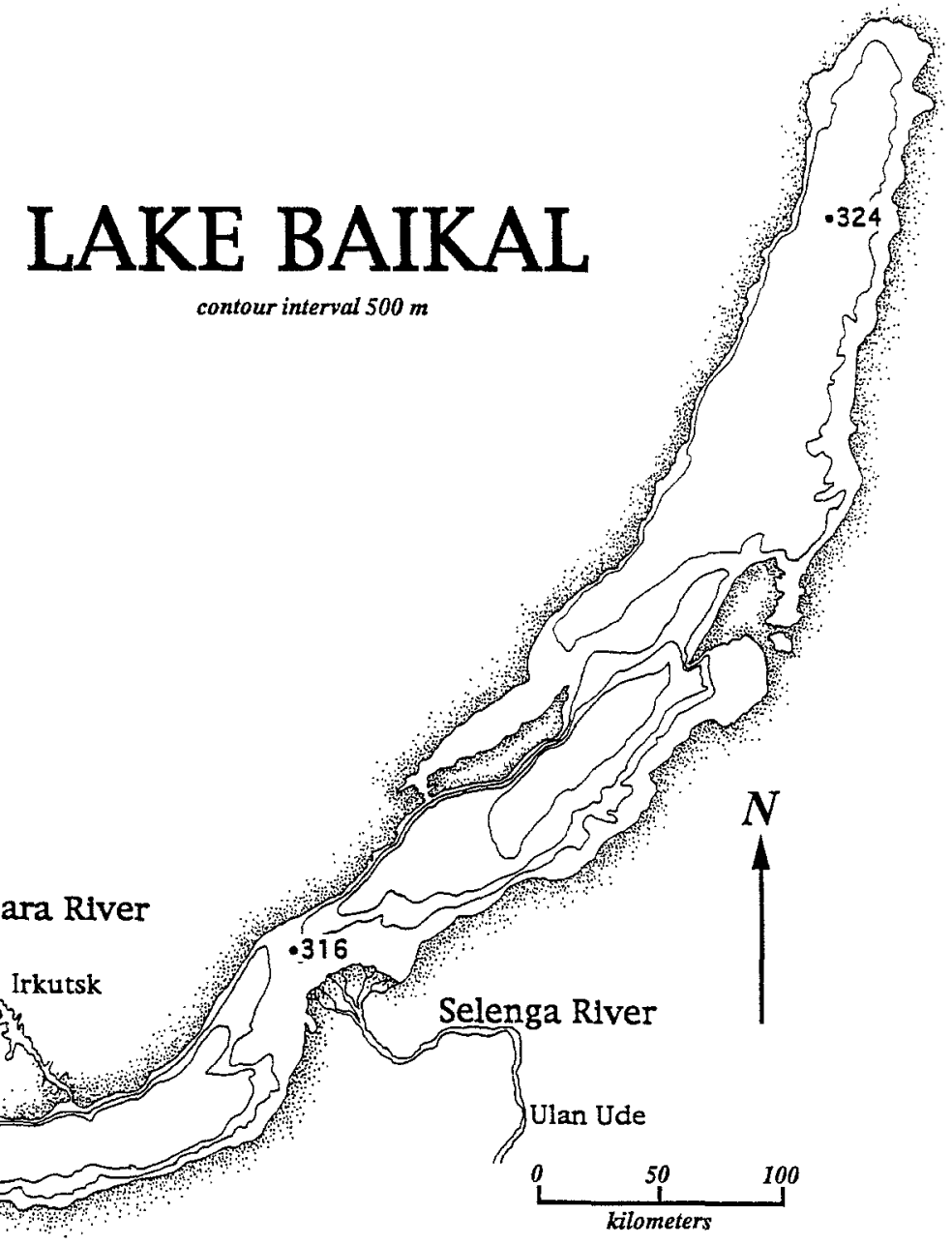

Fig. I. Map of Lake Baikal showing bathymetry and location of coring stations 324 and 316.

mixing rates) of $1.0 \mathrm{~mm} \mathrm{yr}^{-1}$. Using this rate, our Core 316 records an estimated sedimentation history from the 1660's to 1991 A.D. Station 8 from Edgington et al. (1991) was located in Baikal's north basin and their core had a linear sedimentation rate of $0.26 \mathrm{~mm}$ $\mathrm{yr}^{-1}$. With this sedimentation rate used to estimate dates, our Core 324 preserves a sediment record from the late 800 's to 1991 A.D.

\section{Results}

Biogenic silica analysis indicated that the depositional environments of the two sampling sites differ (Fig. 2). On a weight percent basis, Core 316 had less silica content at all depths and it remained relatively constant downcore, ranging only from 19 to 31 weight percent. In contrast, Core 324 had over 80 weight percent in the surface layer, dropped to $43 \%$ by $5.0 \mathrm{~cm}$ and remained near that level downcore, except at 26-27 cm where biogenic silica fell to only $23 \%$.

The distribution of total microfossils in both cores (Fig. 3) was very similar to their respective biogenic silica profiles. Core 324 had greater microfossil abundance at all depths compared to core 316 , except at 26-27 and $28-29 \mathrm{~cm}$. Of the three types of siliceous microfossil remains, diatoms were the most abundant, while chrysophyte cysts made up a significant second portion of both cores. The third category, sponge spicules, were enumerated and found in both cores, but never in great abundance. However, they were included in total microfossil abundance. Because of their size and robust construction, sponge spicules may represent significant portions of biogenic silica in cores (Conley \& Schelske, 1993); however, we believe that 
Table 2. Diatom and chrysophyte taxa used in cluster analysis, Core 316. Taxa chosen were present in five or more sample intervals at $>1 \%$ relative abundance

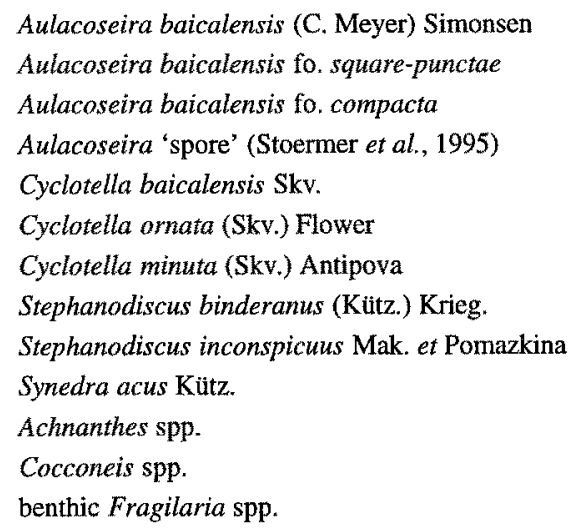

Aulacoseira baicalensis (C. Meyer) Simonsen

Aulacoseira baicalensis fo. square-punctae

Aulacoseira baicalensis fo. compacta

Aulacoseira 'spore' (Stoermer et al., 1995)

Cyclotella baicalensis Skv.

Cyclotella ornata (Skv.) Flower

Cyclotella minuta (Skv.) Antipova

Stephanodiscus binderanus (Kütz.) Krieg.

Stephanodiscus inconspicuus Mak. et Pomazkina

Synedra acus Kütz.

Achnanthes spp.

Cocconeis spp.

benthic Fragilaria spp.

chrysophyte cysts $1,3,22,35$

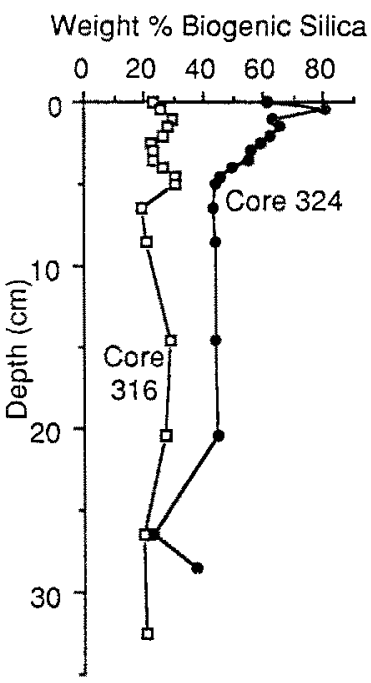

Fig. 2. Weight $\%$ biogenic silica content (g biogenic silica per $100 \mathrm{~g}$ dry sediment) of two Lake Baikal cores (Core 324-filled circles, Core 316-open squares). Vertical scale is depth (cm) from sediment surface.

because of their low abundance in Baikal sediments, their contribution was minimal.

The sedimentary diatom assemblage contained remains of both planktonic and benthic/periphytic diatom communities. In both cores, planktonic diatom remains represented the greatest portion of the assemblage. In the northern basin core (Fig. 4), planktonic diatoms made up between 69 and $79 \%$ of the microfossil assemblage with slightly greater contribution in the upper sediments. Benthic diatom remains made up

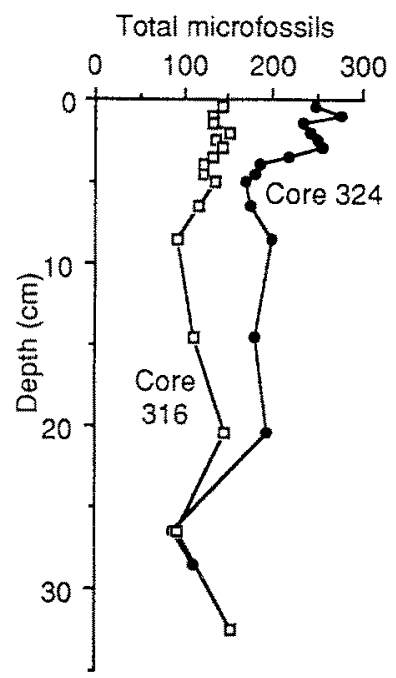

Fig. 3. Total siliceous microfossil abundance (no. $\times 10^{6}$ microfossils per g dry sediment) in two Lake Baikal cores (Core 324-filled circles, Core 316-open squares). Vertical scale as in Fig. 2.

between 1 and $5.6 \%$ with somewhat greater benthic proportions below $4.0 \mathrm{~cm}$. Core 316 had a greater relative proportion of benthic diatoms compared to Core 324, with between 6.7 and $19.6 \%$ (Fig. 5). A peak in benthic abundance occurred at $6-7 \mathrm{~cm}$ with declining abundance downcore. Planktonic diatoms contributed from 77.7 to $85 \%$ of the microfossil assemblage in Core 316 . Their distribution nearly mirrored the benthic diatom assemblage with greatest relative abundance in the 0.5 to $5.0 \mathrm{~cm}$ section with a second peak at $20-21 \mathrm{~cm}$.

Chrysophyte cysts are very common in Lake Baikal sediments and form a morphologically diverse assemblage. Over 100 morphotypes have been identified to date. In Core 324, the nearsurface sediments contained 10 to $15 \%$ cysts, while below $5.0 \mathrm{~cm}$, cysts made up nearly $20 \%$ of the microfossil assemblage (Fig. 4). Core 316 had slightly lower chrysophyte abundance with 6 to $10 \%$ abundance from 0.5 to $5.0 \mathrm{~cm}$ and between 7.5 and $21 \%$ abundance downcore (Fig. 5).

\section{Core 324-North Basin}

To simplify further presentation of results, the distribution of specific taxa and the results of cluster analyses from the two cores will be presented separately.

Cluster analysis on Core 324 resolved four microfossil assemblage zones (Fig. 6). Zone 1 represents samples from the surface to $2.5 \mathrm{~cm}$ and covers estimat- 


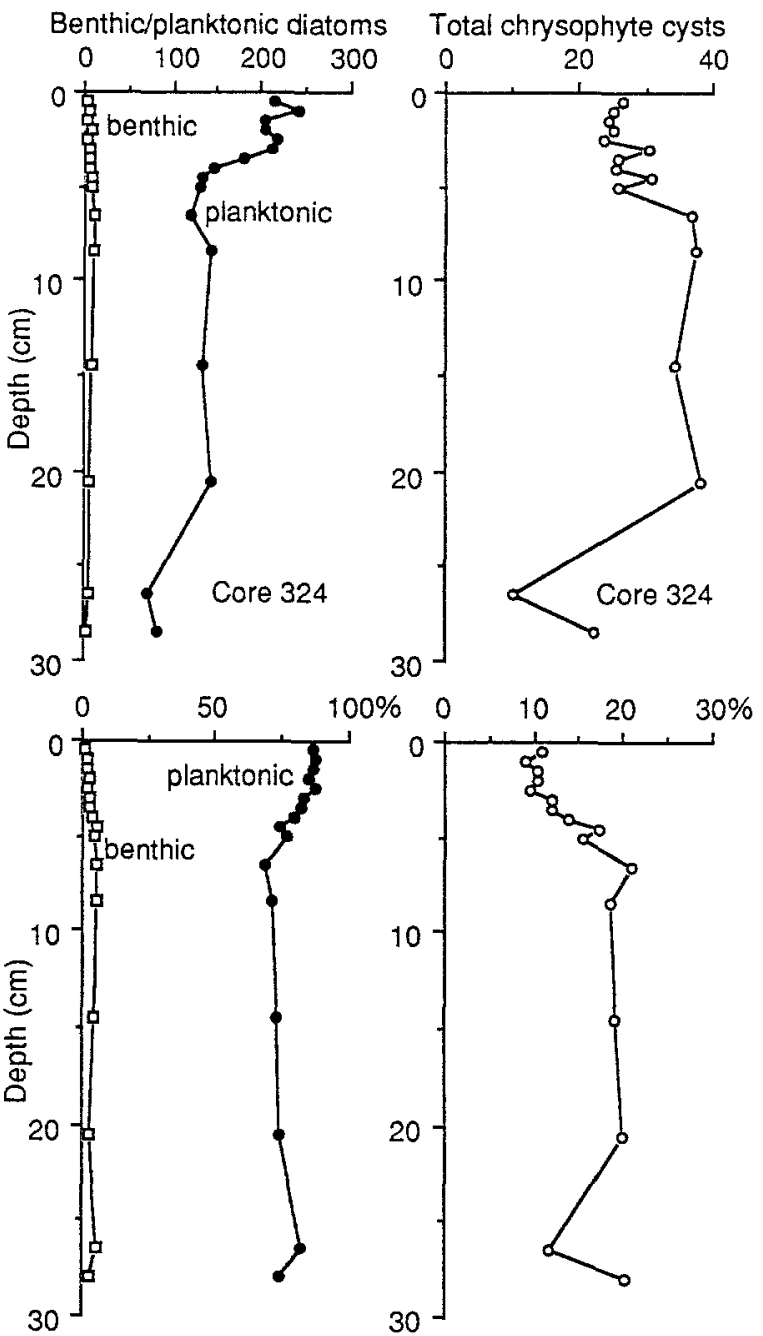

Fig. 4. Absolute abundance (top panels, no. $\times 10^{6}$ microfossils per $g$ dry sediment) and $\%$ relative abundance (lower panels, $\%$ relative to total microfossil assemblage) of benthic and planktonic diatoms and total chrysophyte cysts in Core 324.

ed dates from 1890's to 1991 A.D. Zone 3 (c. 1640's1830 's A.D.) had the highest order of differentiation in our cluster analysis, and represents samples from 4.5 to $8-9 \mathrm{~cm}$. The last cluster incorporates two zones within Core 324 . Zone 2 identifies three samples from 3.0 to $4.0 \mathrm{~cm}$ and represents sediments deposited between the 1830 's and 1890's A.D. Also included in this cluster is Zone 4, the four deepest samples from this core. Dates of Zone 4 are estimated between the 870's and 1450's A.D. and include sediments from $14-15$ to $28-29 \mathrm{~cm}$. These four zones correspond to distinct changes in the absolute and relative abundance of specific taxa that have occurred in the recent history of northern Lake Baikal.

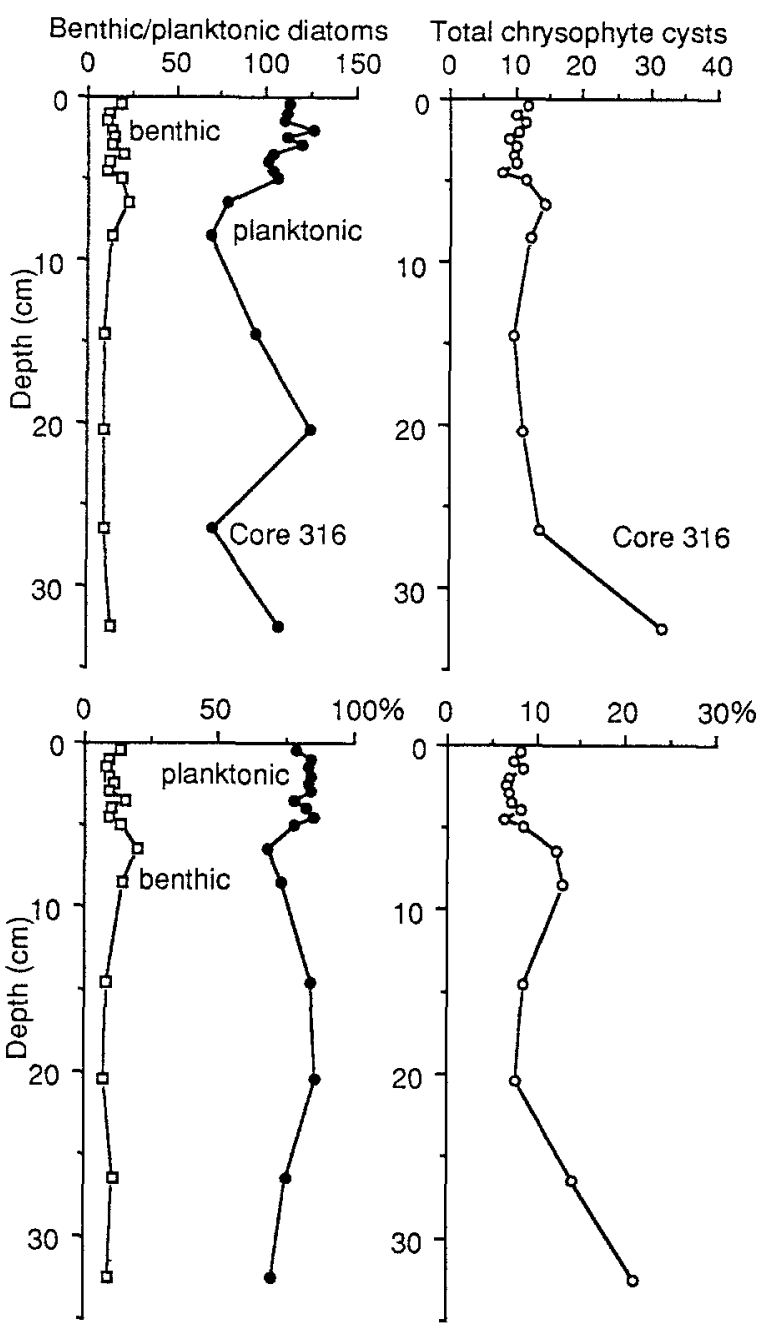

Fig. 5. Absolute abundance (top panels, no. $\times 10^{6}$ microfossils per $\mathrm{g}$ dry sediment) and $\%$ relative abundance (lower panels, $\%$ relative to total microfossil assemblage) of benthic and planktonic diatoms and total chrysophyte cysts in Core 316.

Aulacoseira baicalensis (C. Meyer) Simonsen is the most conspicuous member of the spring plankton community and is an endemic species to Lake Baikal. Aulacoseira baicalensis begins its vernal development especially under clear ice during FebruaryMarch, reaches its population maximum in April, and continues to dominate the plankton until MayJune (D. H. Jewson, pers. comm.). It has a narrow temperature optima of $4-6{ }^{\circ} \mathrm{C}$ and forms physiological resting cells in darkness and during sedimentation (Bondarenko et al., 1993). Its population numbers vary dramatically from year to year producing what are known as 'Aulacoseira' years every 3-4 years (Kozhov, 1963). Valve morphology of $A$. baicalensis is 


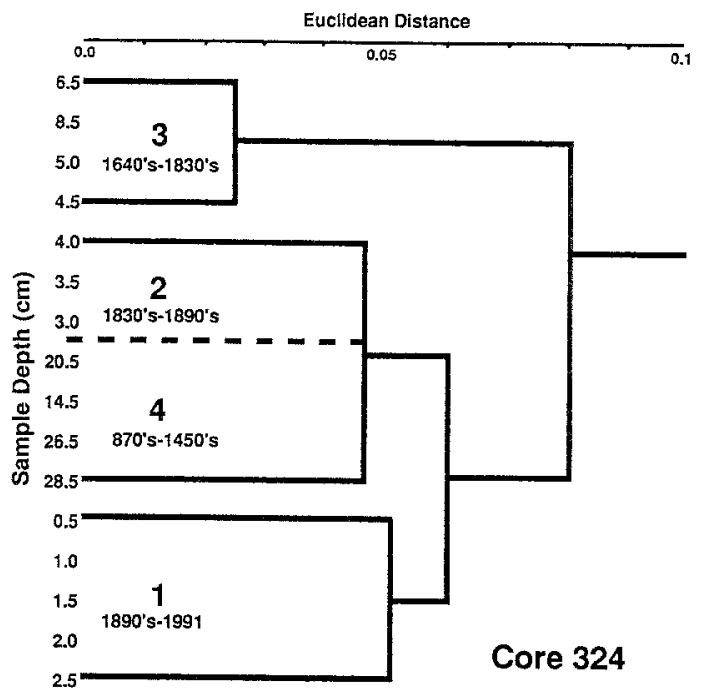

Fig. 6. Cluster analysis based on most abundant diatom taxa and chrysophyte cyst morphotypes (Table 1) in Core 324. Horizontal scale is relative Euclidean distance. Vertical scales represent sample depths, Zones of inferred similarity, and dates associated with Zone boundaries.

extremely variable (Likhoshway et al., 1993), possibly similar to the silica-related variation seen in $A$. islandica (O. Müll.) Simonsen and A. granulata (Ehrenb.) Simonsen (Stoermer et al., 1981). Skvortzow (1937) recognized three formae of this taxon based on degree of silicification and areolar structure; the nominate, fo. compacta, and fo. oblonga-punctata. We also separated three different forms of $A$. baicalensis in our analysis. The most coarsely silicified morphology, fo compacta (Fig. 15), and those valves slightly less silicified, the nominate (Fig. 16), correspond to Skvortzow's (1937) similar formae. The most lightly silicified valve morphology had areolae that appear square in the light microscope. We have termed this form 'squarepunctae' (Fig. 17) in our analyses. It corresponds to Skvortzow's (1937) 'immature' cell wall.

All three forms of $A$. baicalensis were well preserved in Core 324 (Fig. 7). This taxon was the most abundant siliceous microfossil except in sediment Zone 3, where Cyclotella minuta was more abundant. Of the three morphotypes, the coarsely silicified form, A. baicalensis fo. compacta, was most abundant at all levels. It had two abundance peaks in Zones 1 and 4 , at 1.0 and $20-21 \mathrm{~cm}$, respectively. Zone 3 represented the period of lowest relative abundance of $A$. baicalensis in Core 324. The more lightly silicified morphs, the nominate and fo. square-punctae, were present at all levels, but had their greatest development in near sur- face Zone 1 , together making up $>10 \%$ of the assemblage.

A second Aulacoseira species is also found as a less common member of Baikal's plankton and sedimentary assemblage. We feel that it is presently of uncertain taxonomic affinity, and in this study will refer to it as Aulacoseira 'spore' (Figs 18-19) following Stoermer et al. (1995). This taxon has been reported as Melosira baicalensis 'sporangial frustule' (Skvortzow, 1937), A. islandica ssp. helvetica (O. Müll.) Simonsen (Kozhov, 1963; Kozhova et al., 1982), and A. islandica (Genkal \& Popovskaya, 1991; Bradbury et al., 1994). In sedimentary assemblages, it is found nearly exclusively in the resting spore morphology (Fig. 18). Vegetative valves are much more lightly silicified than spores and are subject to breakage and/or dissolution during sedimentation (Fig. 19, arrow). This taxon has similar ecological characteristics as A. baicalensis, i.e. is found most abundantly from March to May, and may bloom under the ice (Kozhova et al., 1982; D. H. Jewson, pers. comm.). Its growth optimum is $4-6{ }^{\circ} \mathrm{C}$, and it forms true resting spores in the absence of light (Bondarenko et al., 1993). In surficial sediment collections, Aulacoseira 'spore' was more common in southern Baikal (Stoermer et al., 1995). Sedimentary distribution of Aulacoseira 'spore' in Core 324 was represented by two peaks in abundance (Fig. 7), the first in the near surface sediment Zone $1(1.0 \mathrm{~cm})$ and maximum abundance in the deepest sediment Zone 4 $(28-29 \mathrm{~cm})$.

Three endemic species of Cyclotella are commonly found in the plankton and sediments of Lake Baikal. All three were originally described as varieties of C. baicalensis (Skvortzow, 1937), but we have separated these three taxa in full agreement with the recent detailed ultrastructural analysis by Flower (1993). The Cyclotella taxa are characteristic of mid-summer to late-fall pelagic plankton collections in Lake Baikal, but can be found year round. They usually have their strongest development in Aulacoseira-poor years. The modern planktonic Cyclotella assemblage is dominated by C. minuta (Skv.) Antipova (Fig. 24). Cyclotella ornata (Fig. 23) and C. baicalensis (Fig. 22) have become less common in recent years (Flower, 1993).

All three Cyclotella taxa had their abundance peaks in Zone 3. Cyclotella baicalensis, the largest taxon, increased in abundance upcore to a peak at $6-7 \mathrm{~cm}$, then generally declined towards the surface sediments except for a small peak at $3.0 \mathrm{~cm}$ (Fig. 8). Cyclotella ornata had greater abundance than $C$. baicalensis at 

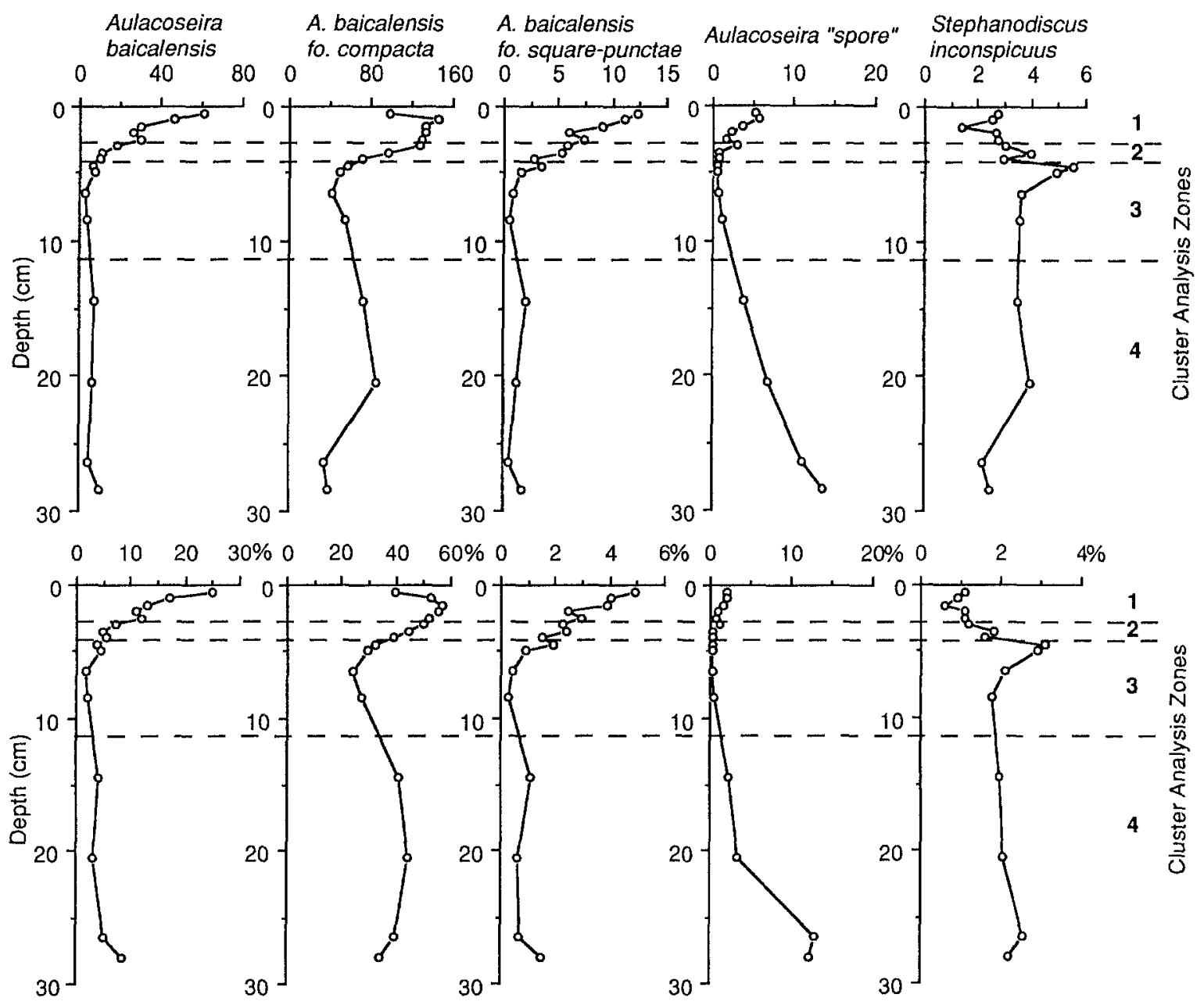

Fig. 7. Absolute (top panels, no. $\times 10^{6}$ microfossils per g dry sediment) and relative (lower panels, \%) abundance of major diatom taxa in Core 324. Left vertical scale is depth $(\mathrm{cm})$ from sediment surface, right scale indicates microfossil succession zones from cluster analysis (Fig. 6).

all depths but had a similar distribution, increasing upcore to a peak at $6-7 \mathrm{~cm}$ in Zone 3 , then decreasing towards the surface (Fig. 8). Cyclotella minuta was the dominant Cyclotella at all depths in Core 324 (Fig. 8). Its lowest absolute abundance was in the bottom two samples (26-27 and 28-29 cm) after which it increased to a peak in relative and absolute abundance in Zone 3. Cyclotella minuta then decreased upcore to a minimum in relative abundance in the top four samples.

Stephanodiscus inconspicuus Mak. et Pomazkina (Figs 25-27) is a small diatom originally reported as Stephanodiscus sp. 2 (Khursevich, 1989; Bradbury et al., 1994), and it has only recently been fully described (Makarova \& Pomazkina, 1992). Stoermer et al. (1995) found $S$. inconspicuus widely distributed throughout surficial sediments in the Baikal basin.
Aspects of its ecology are unknown, but it appears to be another Lake Baikal endemic. Bradbury et al. (1994) suggested that this taxon may be distributed in shallow waters, and related to nutrient input and warm water areas. In Core 324, S. inconspicuus was found in all levels and had a peak in absolute and relative abundance in Zone 3 at $4.5 \mathrm{~cm}$ (Fig. 7). Above and below this depth there was a general decrease in its abundance, with an absolute and relative minimum at $1.5 \mathrm{~cm}$.

In our cluster analyses, all species of benthic Fragilaria (sensu lato) were grouped. Fragilaria identifications must often be made in girdle view in sediment slide preparations which unfortunately do not provide absolute taxonomic certainty at the specific level. However, we feel that the similar ecological role 

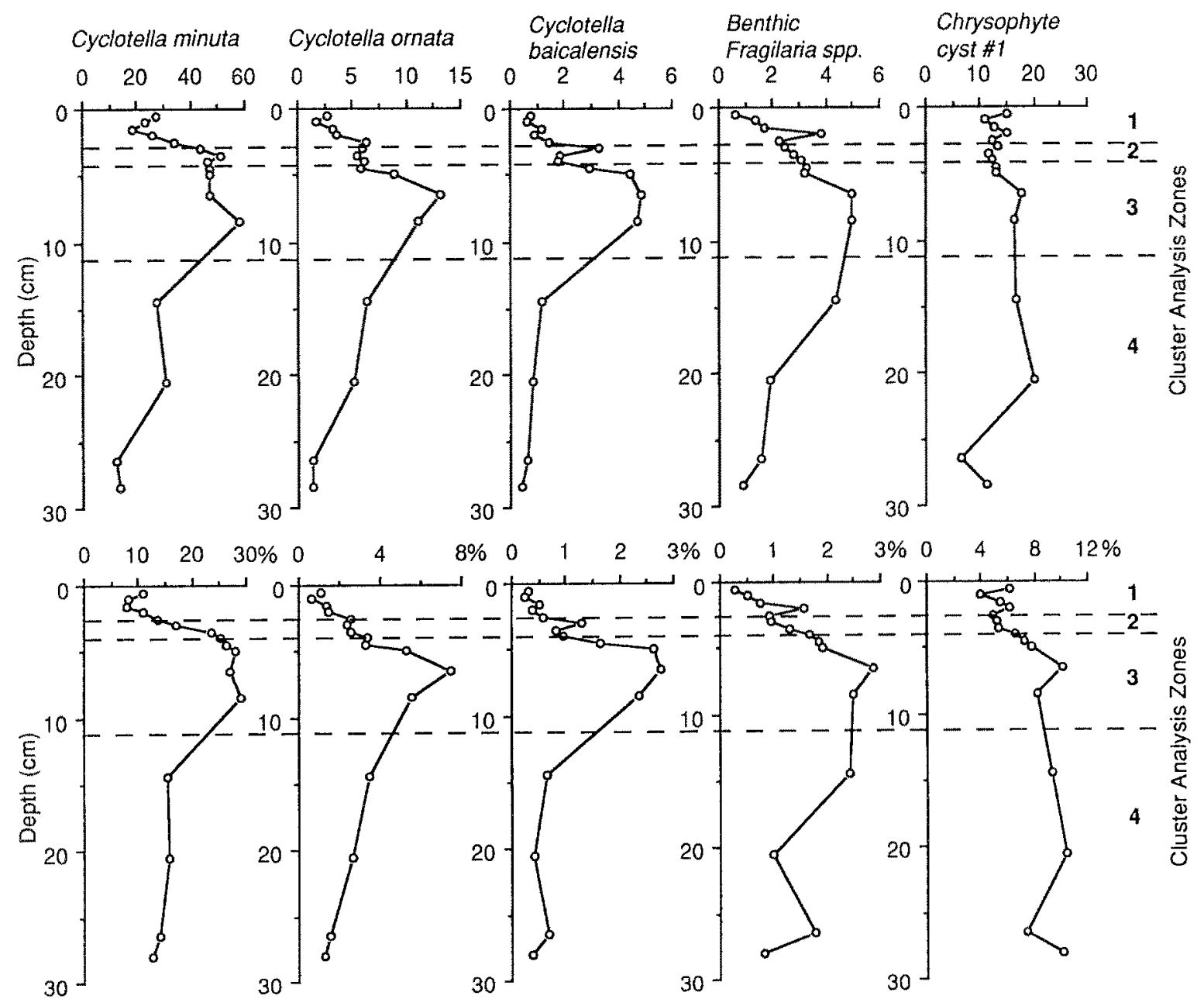

Fig. 8. Absolute (top panels) and relative (lower panels) abundance of some major diatom taxa and chrysophyte cyst \#1 in Core 324. Scale units as in Fig. 7.

that small Fragilaria play justifies grouping these taxa. In Lake Baikal sediments, the small Fragilaria spp. were most commonly F. pinnata Ehrenb., F. construens Ehrenb. and $F$. construens var. minuta Temp, and M. Perag. The benthic Fragilaria ranged in distribution from nearly zero to $3 \%$ relative abundance (Fig. 8 ). Fragilaria increased in abundance upcore from Zone 4 to their peak abundance in Zone 3 at $6-7 \mathrm{~cm}$. Their abundance then generally declined towards the surface sediments except for a small peak at $2.0 \mathrm{~cm}$.

Chrysophyte cysts comprised up to $20 \%$ of the microfossil assemblage at some depths in Core 324. Six different chrysophyte cyst morphotypes were present in sufficient quantity to be included in our cluster analysis. Cyst \#1 (Fig. 28) had generally consistent absolute distribution in the core but had higher relative abundance in downcore Zones 3 and 4 (Fig. 8). Cyst \#3
(Fig. 29) also had its greatest relative abundance in Zones 3 and 4, and fluctuated at lower absolute abundances upcore (Fig. 9). Cyst \#18 (Fig. 30) had relatively stable absolute and relative abundances from 0.5 to $5.0 \mathrm{~cm}$, then increased downcore to a peak in Zone 3 at $8-9 \mathrm{~cm}$ (Fig. 9). Below this depth, cyst \#18 contributed between 4 and $5 \%$ relative abundance except for an absolute and relative minimum at $26-27 \mathrm{~cm}$ (Fig. 9). Cyst \#22 (Fig. 31) had a nearly identical distribution profile as cyst \#18 although was found in slightly less quantity throughout the core (Fig. 9). Cyst \#31 (Fig. 32) had its maximum abundance within Zones 2 and 3, before declining to a minimum at 26$27 \mathrm{~cm}$ downcore. Lastly, cyst \#35 (Fig. 33) exhibited a unimodal sedimentary distribution centered around a peak in Zone 3 at $8-9 \mathrm{~cm}$, and declined in absolute and relative abundance both up and downcore (Fig. 9). 

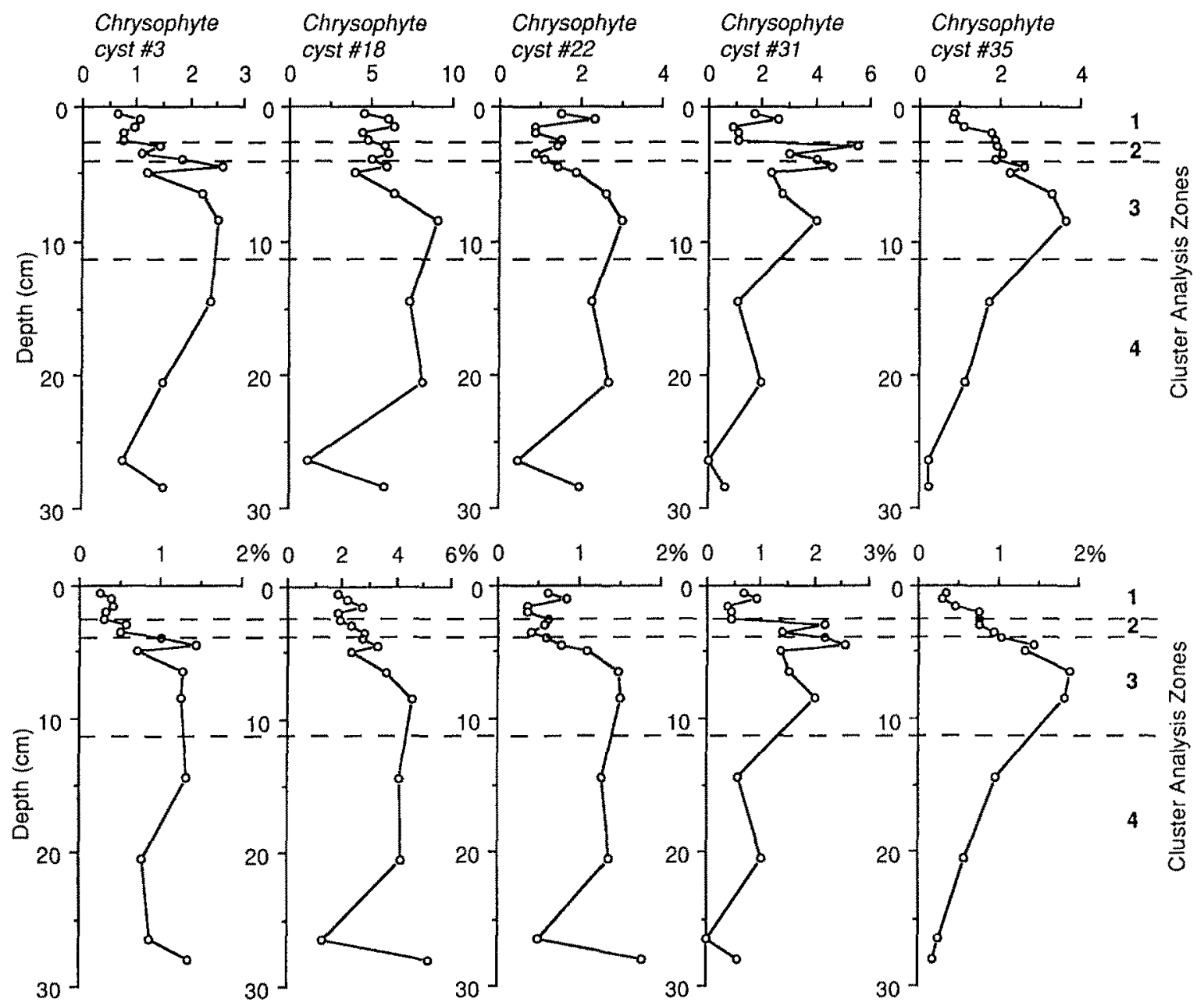

Fig. 9. Absolute (top panels) and relative (lower panels) abundance of some major chrysophyte cyst morphotypes in Core 324. Scale units as in Fig. 7.

\section{Core 316-Central/Southern Basin}

Cluster analysis performed on the Core 316 assemblages revealed four distinct zones of microfossil succession (Fig. 10). One cluster, Zone 3, was represented by a single depth, $20-21 \mathrm{~cm}$. This depth approximately corresponds to sediments laid down during the late 1700's. Zone 1 clustered sediments levels from 0.5 to $4.0 \mathrm{~cm}$ which were estimated to date between the early 1950's and 1991 A.D. Zone 2 (c. 1840's1940's A.D.) resolved sediment depths from 5.0 to 14-15 cm. The last cluster, Zone 4, groups the two lowest depths Core $316,26-27$ and $32-33 \mathrm{~cm}$. These deepest sediments have been estimated to date between the 1660's and 1730's A.D. In presenting the distribution of specific taxa from Core 316 , we will refer to their abundance within these four cluster analysis zones (Fig. 10).

All three morphologies of Aulacoseira baicalensis were present in each depth of Core 316 , with A. baicalensis fo. compacta (Fig. 15) the dominant morphotype at all levels (Fig. 11). The three morphotypes had their greatest abundance in Zone 1 sediments. Below Zone 1, the absolute and relative abundances of all morphotypes declined sharply. Aulacoseira baicalensis fo. square-punctae (Fig. 17) and the nominate variety (Fig. 16) were present only in very low abundance below $4.5 \mathrm{~cm}$. Aulacoseira baicalensis fo. compacta (Fig. 15) continued to be the dominant morphotype downcore, contributing slightly less than $5 \%$ relative abundance in Zones $2-4$.

Aulacoseira 'spore' (Figs 18-19) was found at its greatest abundance in the Zone 1 sediments from 0.5 


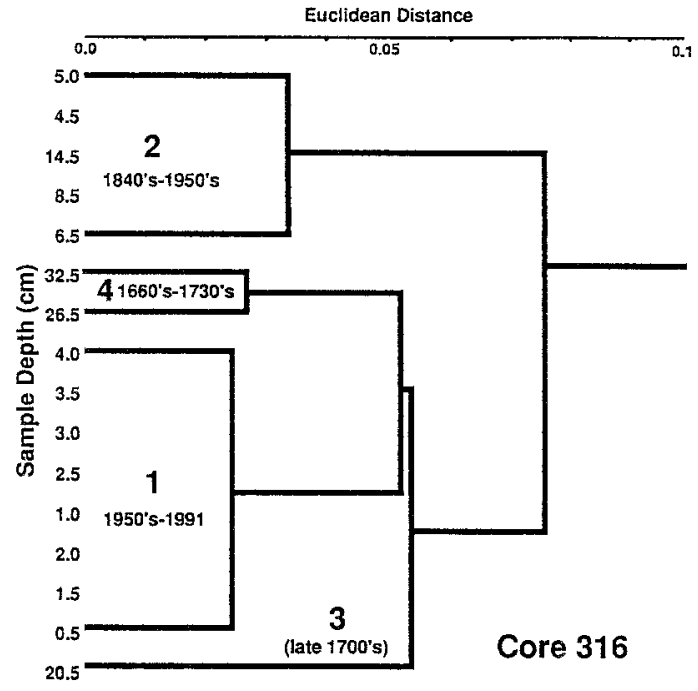

Fig. 10. Cluster analysis based on most abundant diatom taxa and chrysophyte cyst morphotypes (Table 2) in Core 316 . Horizontal scale is relative Euclidean distance. Vertical scales represent sample depths, Zones of inferred similarity, and dates associated with Zone boundaries.

to $4.0 \mathrm{~cm}$. Below this depth it had relatively constant low abundance before a slight increase in Zone 4 of Core 316 (Fig. 11).

Cyclotella minuta (Fig. 24) was the most common Cyclotella taxon in Core 316. It was the dominant taxon downcore before sharply decreasing to its lowest relative abundance in Zone 1 (Fig. 12). It had a strong absolute abundance peak at 4.5 and $5.0 \mathrm{~cm}$ in Zone 2 and a downcore absolute minimum at $26-27 \mathrm{~cm}$ in Zone 4, although it still represented $30 \%$ of the microfossil assemblage at that depth. Cyclotella ornata (Fig. 23) had a very similar pattern of distribution as C. minuta, indicating autecological similarity. It was generally at lowest relative abundance in Zone 1 sediments (Fig. 12). Two peaks of absolute and relative abundance occurred in Zone 2 at 4.5 and $14-15 \mathrm{~cm}$. In downcore Zones 3 and 4, C. ornata represented between 6.5 and $9.0 \%$ relative abundance. The largest Baikal endemic Cyclotella, C. baicalensis (Fig. 22), was the least abundant member of this genus at all depths (Fig. 12). It too was found at low abundance in Zone 1 sediments, but increased downcore to generally contribute between 1 to $3 \%$ relative abundance.

Both Stephanodiscus binderanus (Kütz.) Krieg. and S. binderanus var. baicalensis Popovsk. et Genkal have been reported from Lake Baikal (Fig. 20). However, because their identification in sediments must often be made in girdle view (Fig. 20), the two vari- eties are sometimes indistinguishable, and we have grouped them under the nominate variety. This diatom has been reported from Lake Baikal since the 1930's (Skvortzow, 1937). It is a vernal taxon in shallow areas, particularly some of the larger bays (Kozhov, 1963) but also has strong development in some years in pelagic waters (Popovskaya, 1991). In the Laurentian Great Lakes, $S$. binderanus is common in more eutrophic inshore waters, and is found in spring offshore collections in the lower lakes (Stoermer \& Yang, 1969).

The distribution of $S$. binderanus in Core 316 was characterized by relative and absolute abundance peaks in Zones 1 and 3 (Fig. 12). Zone 3 was represented by a single sample that had greater than $20 \%$ relative abundance of $S$. binderanus. A very sharp increase in abundance between samples 4.5 and $4.0 \mathrm{~cm}$ delimits the separation between Zones 2 and 1 .

Stephanodiscus inconspicuus (Figs 25-27) was found in all sediment depths of Core 316 , but had its greatest absolute abundance in near surface sediment Zone 1 (Fig. 11). Moving downcore there was a second abundance peak in Zone 2 at $14-15 \mathrm{~cm}$ before abundances dropped to constant levels through Zones 3 and 4.

Synedra acus (Fig. 21) has become an increasingly important member of the Baikal plankton. It is found year-round, but most prominently from April-June. It has noticeably increased in abundance since the 1950's (Popovskaya, 1993), and has been shown to have a wide breadth of growth optima (Bondarenko et al., 1993). It has also apparently been a conspicuous member of the plankton during the history of Baikal. Bradbury et al. (1994) reported on its periodic occurrence since the late Pleistocene in Lake Baikal, suggesting its association with more nutrient input and warmer climates. Sedimentary remains of $S$. acus were usually fragmented.

Synedra acus had two abundance peaks in Core 316 (Fig. 12). The first occurred in near surface Zone 1 with maximum abundance at $1.5 \mathrm{~cm}$. The second peak was in Zone 4 and represented the absolute and relative abundance maximum for $S$. acus.

Because of their similar ecological role in the diverse periphyton of Lake Baikal (Skvortzow, 1937; Foged, 1993), Achnanthes and Cocconeis taxa were each grouped at the generic level for statistical analyses. Achnanthes species most commonly encountered in Core 316 sediments were A. oestrupi (A. Cl.) Hust., A. lanceolata (Bréb.) Grun., A. calcar $\mathrm{Cl}$., A. striata Skv. and C. Meyer, and A. minutissima Kütz. The Cocconeis assemblage was dominated by $C$. placen- 
tula var. baicalensis Skv., C. placentula var. lineata (Ehrenb.) V. H., and C. thumensis Mayer. Achnanthes spp. had nearly constant relative distribution throughout the core contributing between 0.64 and $1.7 \%$ (Fig. 13). Three relative and absolute abundance maxima occurred at $2.5,6-7$, and $26-27 \mathrm{~cm}$. Cocconeis spp. were also distributed at nearly constant relative abundance downcore (Fig. 13). In general, however, they had their greatest absolute abundance in Zone 1, with secondary peaks at 8-9 $\mathrm{cm}$ in Zone 2 and in Zone 4 .

The small benthic Fragilaria taxa were also grouped in Core 316, similar to Core 324 . The Fragilaria assemblage contributed $>2 \%$ relative abundance at all core depths except at $14-15 \mathrm{~cm}$ in Zone 2 (Fig. 13). Two peaks in relative abundance occurred at $3.5 \mathrm{~cm}$ and $8-9 \mathrm{~cm}$.

Fewer chrysophyte cyst morphotypes met our inclusion criteria for cluster analy sis of Core $316 \mathrm{com}$ pared to Core 324 . The four that were included, however, had also been selected for the Core 324 cluster analysis. Cysts \#1 (Fig. 28) and \#3 (Fig. 29) had similar distributions in Core 316 (Fig. 13). Both had highest abundances in Zone 4 and then dropped to approximately $2 \%$ relative abundance through Zones 2 and 3 . At the top of Zone 2, abundances fell to $<2 \%$ where they remained to the surface. Cyst \#22 (Fig. 31) had quite variable distribution in the core. It was found in greatest absolute and relative abundance in the top-and bottom-most depths (Fig. 14). Cyst \#35 (Fig. 33) had two peaks in abundance in Zones 2 and 3 at $8-9$ and 20-21 cm respectively (Fig. 14). Lower abundances of cyst \#35 were generally found in Zones 1 and 4 except for a local minimum at $14-15 \mathrm{~cm}$.

\section{Discussion}

Lake Baikal has no modern analog. Its size, depth, and latitudinal position create unique limnological conditions and, because of the lake's great age and relative geographic isolation, the Baikal flora and fauna have developed an extremely high degree of endemism. Endemism is reflected at all levels of the food web, and is especially evident in the diatom community. The plankton community is represented by very few endemic taxa adapted to Baikal's unique pelagic environment (Skvortzow, 1937; Bradbury et al, 1994). This phenomenon of nondiverse plankton is not observed in other large Pleistocene-age lakes (Stoermer \& Yang, 1969). The benthic and periphytic diatom communities have also developed endemically but contrary to planktonic assemblages are extremely diverse and contain 'swarms' of related species (Skvortow \& Meyer, 1928; Skvortzow, 1937; Stoermer et al., 1986; Kociolek \& Stoermer, 1988; Foged, 1993). This confounds any effort to create a modern analytical calibration set (Fritz et al., 1991) for resolving downcore changes in Lake Baikal's past. Our downcore interpretations of siliceous microfossil remains must instead be based on autecological characteristics of Baikalian algae, an analytical approach that has proven successful in paleolimnological interpretations of other large lake systems (Stoermer et al., 1993).

The sedimentary environment in Lake Baikal is characterized by extremely high biogenic silica levels and large depositional zones (Williams et al., 1993). In contrast, large Pleistocene-age lakes often have discrete depositional basins and an order of magnitude less sedimentary biogenic silica content than Lake Baikal (Stoermer et al., 1985b). Characteristics of Baikal that create these sedimentary conditions are its great depth, steep sided basin morphometry, rather high levels of dissolved silica, cold waters, and incomplete vernal and autumnal mixing (Weiss et al., 1991; Granina et al., 1993; Williams et al., 1993). Biogenic silica profiles of Cores 324 and 316 also reflected the difference in depositional environments between the northern and southern basins, with much greater silica content in northern basin sediments (Fig. 2). Several studies (Granina et al., 1993; Williams et al., 1993; Stoermer et al., 1995) have documented identical trends and suggested that biogenic silica sedimentation patterns in Lake Baikal reflect both the slightly higher water column silica values in the northern basin and, in southern Baikal sediments, dilution by terrigenous clastic inputs, especially from the Selenga River (Fig. 1). This dilution factor masks sedimentary signals of greater water column productivity in the south.

The northern basin of Lake Baikal is removed from most direct anthropogenic impacts affecting the central and southern basins. It has lower productivity and less terrigenous input than the southern basin. Modern phytoplankton assemblages are dominated by the endemic Aulacoseira and Cyclotella with very few of the more ubiquitous diatoms encountered in southern Baikal (Stoermer et al., 1995). The four successional zones resolved with cluster analysis (Fig. 6) of Core 324 were separable based on their assemblage characteristics, and we suggest that these changes reflect climatic patterns over the last $\sim 1100$ years. The most recent sediments in the northern basin (Zone 1, c. 1890's-1991 A.D.) were characterized by an increased abundance 

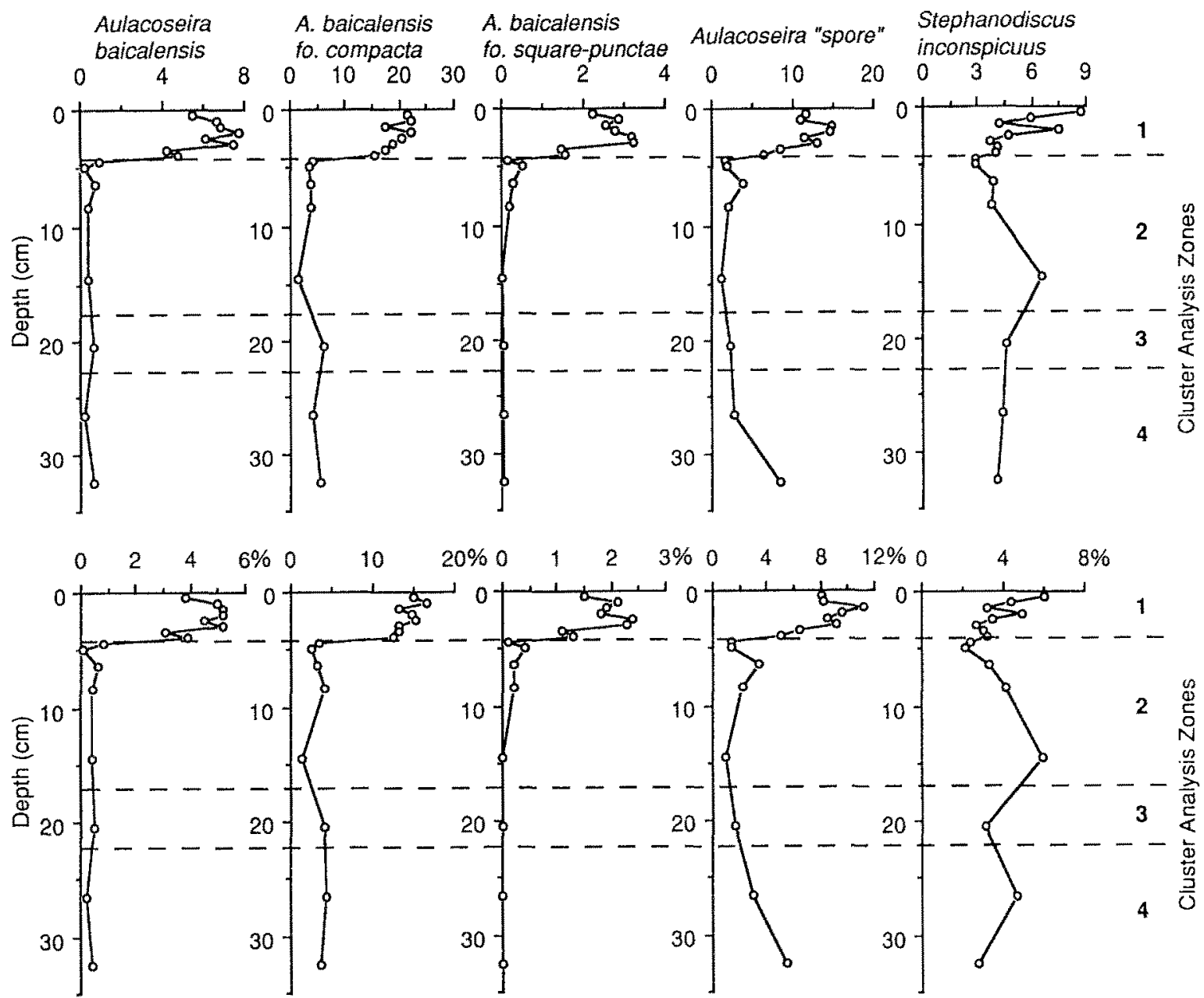

Fig. 11. Absolute (top panels, no. $\times 10^{6}$ microfossils per $\mathrm{g}$ dry sediment) and relative (lower panels, \%) abundance of some major diatom taxa in Core 316. Left vertical scale is depth $(\mathrm{cm})$ from sediment surface, right scale indicates microfossil succession zones from cluster analysis (Fig. 10).

of Aulacoseira baicalensis and Aulacoseira 'spore' (Fig. 7). Zones 1 and 2 also identify a period of increasing biogenic silica accumulation in northern Lake Baikal (Fig. 2). Zone 1 sediments encompass the recent climatic warning that had its maximum c. 1940 A.D. (Khotinskiy, 1984). The abundance of vernal Aulacoseira taxa and increased biogenic silica accumulation suggests warmer climates associated with longer, more productive vernal growth and milder winter conditions. However, caution should be exercised when correlating these recent assemblage changes and productivity increases solely to climatic variables. In other ultraoligotrophic north temperate lakes, recent assemblage shifts appear to also reflect unique changes associated with modern day atmospheric loadings (Stoermer et al., 1985c; Stoermer et al., 1990).
In contrast, Zone 3 sediments (c. 1640's-1830's A.D.) were dominated by the endemic Cyclotella with reduced abundance of Aulacoseira. Estimated dates from Zone 3 correspond to a climatic period, known as the Little Ice Age (late 1400's to 1850 A.D.), which was characterized by cooler climatic conditions in Siberia (Khotinskiy, 1984). The shift in dominance in the planktonic community from Aulacoseira to Cyclotella provides an indicator of this climate change. During cooler conditions, heavier ice and possibly snow cover would decrease light penetration below the ice and shorten the spring turnover period, thereby limiting late winter and vernal growth of the endemic Aulacoseira taxa (Lund, 1966; D. H. Jewson, pers. comm.). Concomitantly, greater abundance of the dominant summer and autumn planktonic Cyclotella would be expect- 

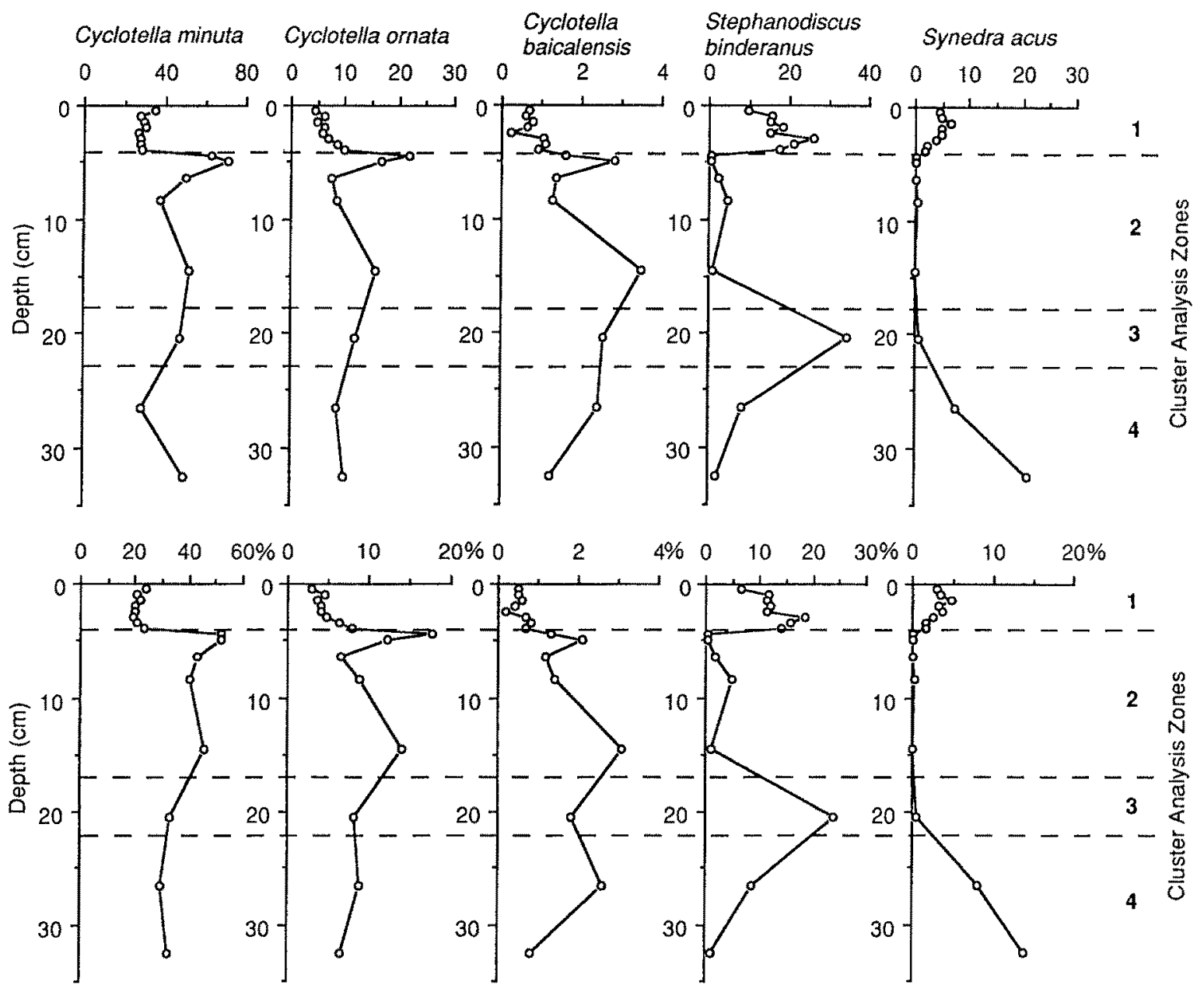

Fig. 12. Absolute (top panels) and relative (lower panels) abundance of some major diatom taxa in Core 316. Scale units as in Fig. 11.

ed. The microfossil assemblage between Zones 1 and 3 (Zone 2, c. 1830's-1890's A.D.) and in Zone 4 (c. 870 's-1450's A.D.) are similar to one another (Fig. 6) suggesting they represent transitional intervals between cooler and warmer climates as Baikal's plankton shifted between Cyclotella and Aulacoseiradominated assemblages. Bradbury \& Dieterich-Rurup (1993) interpreted a similar shift in planktonic dominance from Fragilaria crotonensis Kitton to Stephanodiscus minutus Grun. in Elk Lake, Minnesota, as a response to cooler conditions during the Little Ice Age.

Other taxa showing similar downcore patterns between Zones 1 and 3 of Core 324 as the Cyclotella spp. are chrysophyte cyst \#35 (Fig. 9), Stephanodiscus inconspicuus (Fig. 7), and the benthic Fragilaria spp. (Fig. 8). While we know little about the ecology of the Baikal chrysophytes, increased deposition of cysts has been correlated to persistence of higher productivity into summer (Bradbury \& Dieterich-Rurup, 1993), a condition that would have also promoted strong growth of the endemic Cyclotella. Relatively high abundance of Fragilaria and $S$. inconspicuus during the Little Ice Age period would also be expected. Along with these two taxa, the grouped benthic taxa also had their maxima in Zone 3 sediments (Fig. 4) suggesting enhanced microfossil contribution from shallow water productivity relative to offshore production during this cooler climate period. Thicker ice cover and lengthier ice breakup periods during cooler climates may have produced extended periods with ice-free bays and shallows similar to the moat hypothesis of Smol (1988).

In contrast to the north basin, the southern end of Lake Baikal has been the site of some regional urbanization and industrialization. Impacts on the lake from atmospheric and direct loadings are cen- 

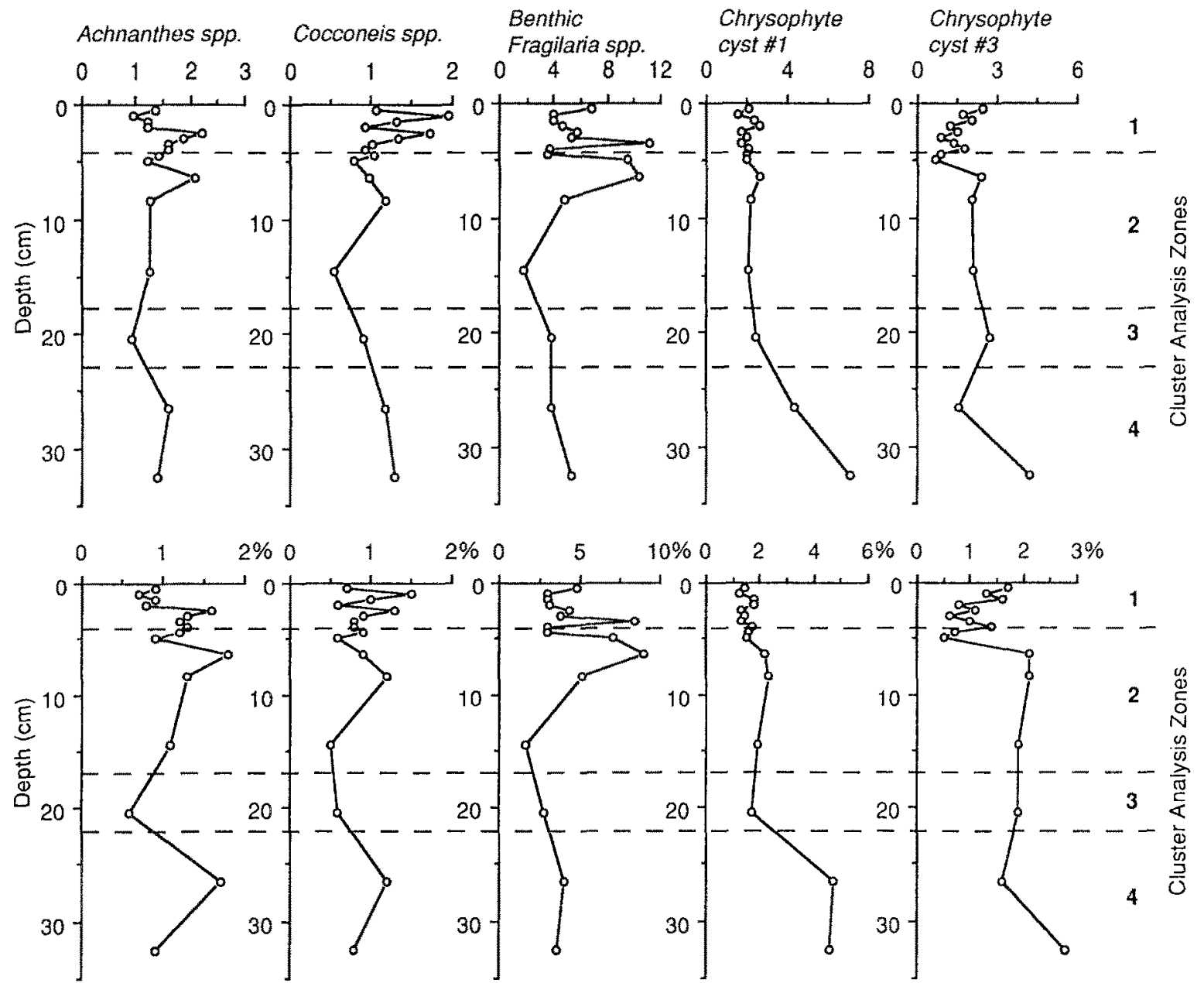

Fig. 13. Absolute (top panels) and relative (lower panels) abundance of some major benthic diatom taxa and chrysophyte cyst morphotypes in Core 316. Scale units as in Fig. 11.

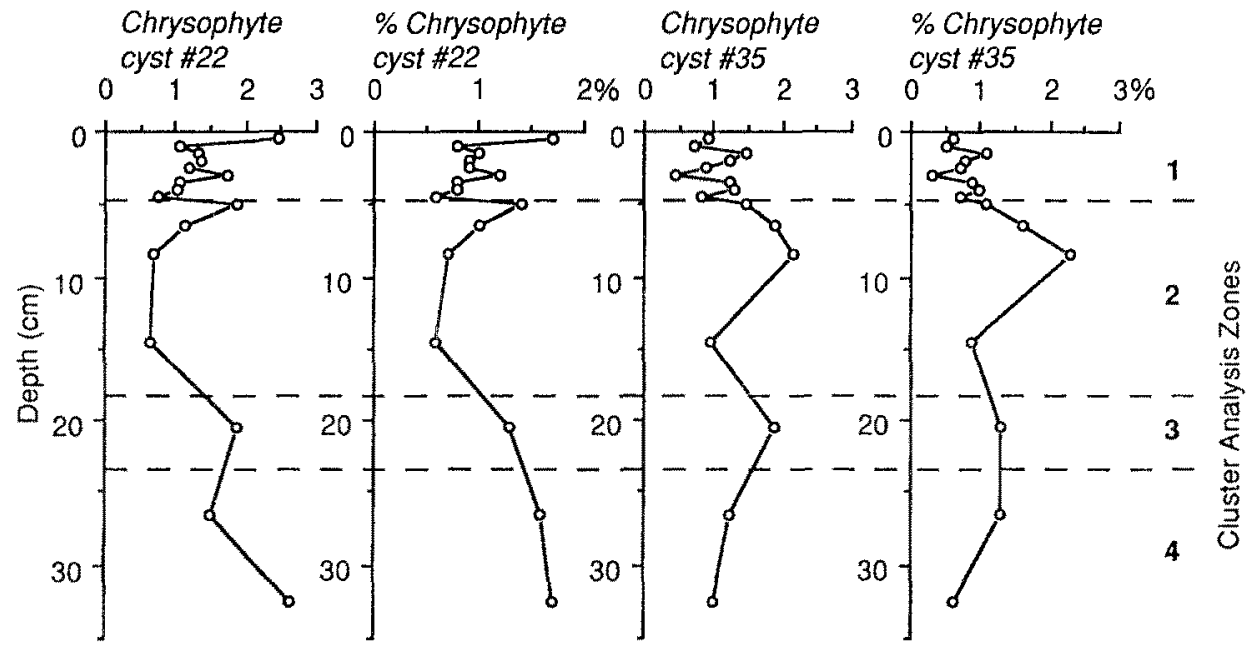

Fig. 14. Absolute (panels 1\&3) and relative (panels 2\&4) abundance of two major chrysophyte cyst morphotypes in Core 316 . Scale units as in Fig. 11. 

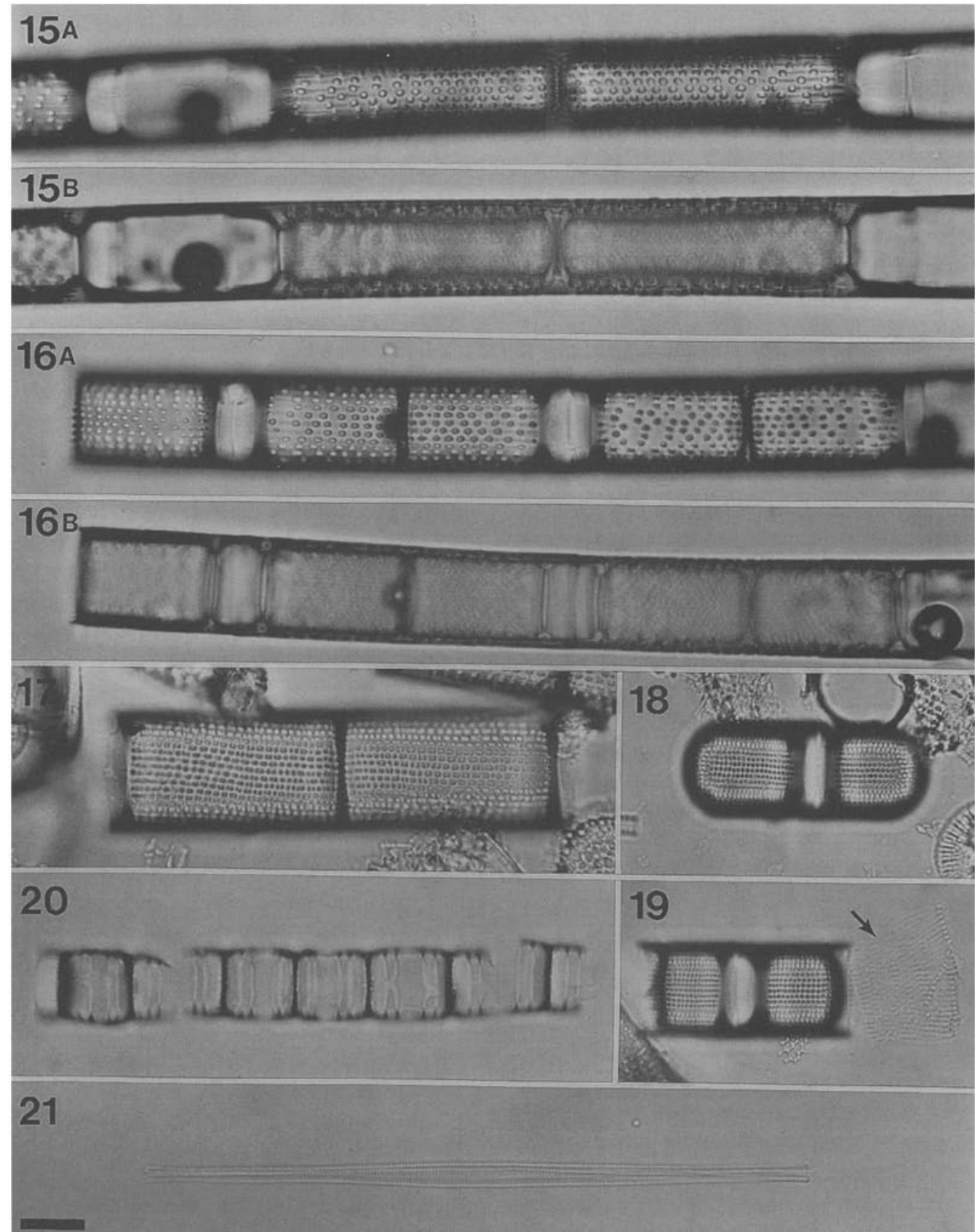

Plate 1. Dominant Lake Baikal diatoms found in sediment assemblage. Scale bar $=10 \mu \mathrm{m}$. All figures at same magnification (Scale bar in Fig. 21). Fig. 15. Aulacoseira baicalensis fo. compacta. Fig. 15a. High focus. Fig. 15b. Mid-focus showing extreme thickness of valve mantle Fig. 16. Aulacoseira baicalensis nominate form. Fig. 16a. High focus. Fig. 16b. Mid-focus showing thinner mantle region. Fig. 17. Aulacoseiro baicalensis fo. square-punctae. Figs 18-19. Aulacoseira 'spore', note collapsed remains of vegetative frustule in Fig. 19 (arrow). Fig. 20. Stephanodiscus binderanus. Fig. 21. Synedra acus. 


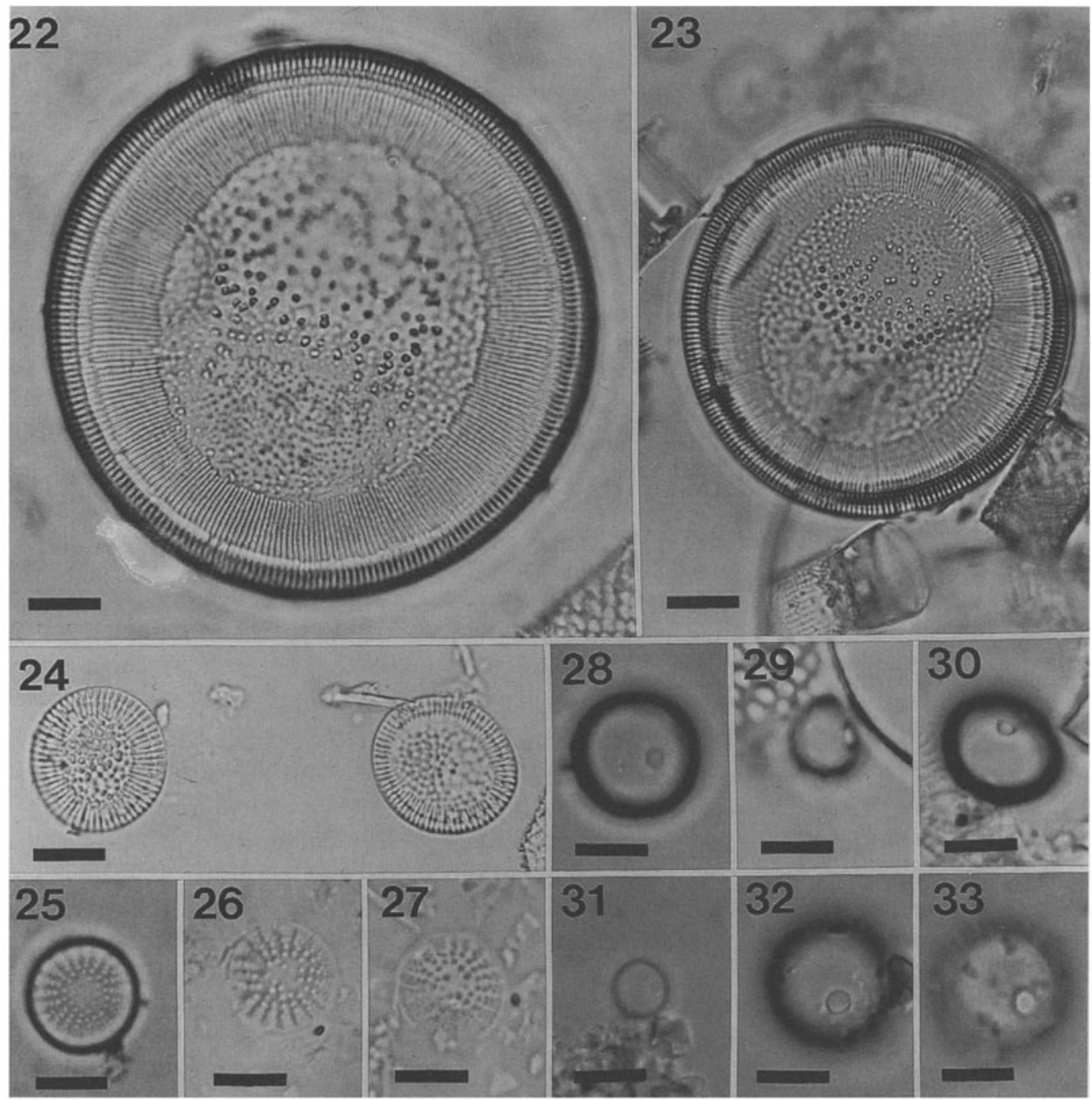

Plate 2. Dominant Lake Baikal diatoms and chrysophyte cysts found in sediment assemblage. Scale bars $=10 \mu \mathrm{m}$ for Figs $22-24$, scale bars $=5 \mu \mathrm{m}$ for Figs 25-33. Fig. 22. Cyclotella baicalensis. Fig. 23. Cyclotella ornata. Fig. 24. Cyclotella minuta. Figs 25-27. Stephanodiscus inconspicuus. Fig. 28. Baikal chrysophyte cyst \#1. Fig. 29. Baikal chrysophyte cyst \#3. Fig. 30. Baikal chrysophyte cyst \#18. Fig. 31. Baikal chrysophyte cyst \#22. Fig. 32. Baikal chrysophyte cyst \#31. Fig. 33. Baikal chrysophyte cyst \#35.

tered around industrial towns and sites on the southern shore and loading from upstream cities (Ulan Ude and Selengisk) on the Selenga River (Fig. 1; Galazii, 1991; Belt, 1992). Confounding sedimentary inter- pretation of anthropogenic effects on the lake are climatic changes that must have also affected southern Baikal. 
Core 316 preserved a much shorter history than Core 324 , thus presettlement conditions are poorly resolved. Higher sedimentation rates found between Baikal's southern and central basin (Edgington et al., 1991) allowed recovery of a record extending from c. 1660's-1991 A.D. Our cluster analysis resolved four zones of microfossil succession in Core 316 (Fig. 10), Zone 1 (c. early 1950 's-1991 A.D.) corresponds to post-World War II industrialization, a period when planktonic communities became dominated by endemic Aulacoseira (Fig. 11). The increase in Aulacoseira abundance is probably indicative of both the recent climatic warming (Khotinskiy, 1984) and increased productivity from nutrient loadings. An increased abundance in Zone 1 of nonendemic diatoms, such as Stephanodiscus binderanus (Fig. 12), Synedra acus (Fig. 12), and Cyclostephanos dubius (Fricke) Round (not figured), all considered more eutrophic taxa, also lends credence to a hypothesis that anthropogenic impacts from development and increased nutrient loadings have occurred in this region of Lake Baikal. These changes also appear to have impacted certain chrysophyte populations in southern Baikal. Cysts \#1, \#3, and \#35 experienced reduced abundance in the transition from Zone 2 to Zone 1 (Figs 13, 14).

In sediments predating Zone 1 in Core 316 (Zones 2-4, c. 1660's-1950's A.D.), endemic Cyclotella taxa dominated the planktonic community in southern Lake Baikal (Fig. 12). Zone 2 sediments (c. 1840's-1950's A.D.) were also characterized by decreased Aulacoseira abundance (Fig. 11). Zone 2 may represent restabilization following initial European occupation of the region. Similar 'relaxation' of eutrophication following initial destruction of forests is commonly noted in cores from the Laurentian Great Lakes (Stoermer et al., 1993).

Zone 3 is represented by a single depth $(20-21 \mathrm{~cm})$ and is uniquely characterized by an abundance peak of Stephanodiscus binderanus that had begun in Zone 4 . This depth has been dated c. 1780's A.D., and may indicate that anthropogenically-induced changes occurred in Lake Baikal during early settlement and development in the southern basin. This date corresponds roughly to a time period when Irkutsk and Ulan Ude were seeing significant Russian expansion and development. Changes in the lake may have been driven by nutrient loadings from land clearance, slash and burn agriculture, and urban loading along the Selenga River (Riasanovsky, 1984). Apparently the diatom community responded with increased production of smaller taxa (S. binderanus) since the 20-21 cm depth was a local maximum of absolute microfossil abundance but did not show increased biogenic silica deposition (Figs 2,3). The most recent sedimentary assemblages in Core 316 suggest that a similar response has occurred in southern Baikal since the early 1950's (0.5$4.0 \mathrm{~cm}$ in Fig. 3), supporting Popovskaya's (1991) observed increase of small-celled species in the plankton since 1958. The appearance of $S$. binderanus was still overshadowed by dominance of the endemic Cyclotella taxa during Zone 3, which suggests that nutrient enrichment was probably most prevalent in nearshore areas of southern Baikal. In the Laurentian Great Lakes $S$. binderanus may form dense nearshore blooms with little invasion of offshore waters (Lorefice \& Munawar, 1974).

The two lowest depths in Core 316 were resolved as Zone 4 (c. 1660's-1730's A.D.). This zone had abundant Cyclotella but was also characterized by increases in Synedra acus and Aulacoseira 'spore' (Figs 11, 12). The few samples available make interpretation difficult but, following previous arguments, these samples were likely deposited under conditions that allowed maximum growth of summer-blooming taxa.

The climatic signals recorded in the planktonic assemblages in Core 324 should also provide evidence of Late Holocene climatic shifts in future downcore interpretations. Historical vegetation patterns in Siberia suggest that there have been many major and minor climatic optima since the last glaciation (Khotinskiy, 1984) which should be reflected in northern basin sediments. The southern sediment record provides strong evidence that Lake Baikal is no longer in its pristine state. The appearance of nonendemic diatoms in Baikal points towards changes that have occurred quite dramatically since World War II, which are probably associated with industrialization and urbanization around southern Baikal and along the Selenga River. Changes in the primary producer communities should act as a harbinger of the potential for future changes in all levels of the food chain. In other formerly oligotrophic large lake systems that experienced anthropogenic impacts, changes in primary production levels and assemblage characteristics identified with paleolimnological analysis were the first signs of environmental impact and future problems (Stoermer et al., 1985b). 


\section{Acknowledgments}

We wish to thank D. H. Jewson for valuable discussion on Aulacoseira ecology, J. Paduan for sample analysis, and D. Francis for help in preparing illustrations. Collection of sediments was supported by the U.S. Geological Survey, the Russian Limnological Institute, and National Geographic Research Grant $4272-90$ to CHP. Contribution number 572 from the Center for Great Lakes and Aquatic Sciences was supported in part by NSF Grant EAR-9119537.

\section{References}

Battarbee, R. W., 1973. A new method for estimating absolute microfossil numbers with special reference to diatoms. Limnol. Oceanogr. 18: 647-653.

Belt, D., 1992. The World's Great Lake. National Geographic 181: 2-39.

Bondarenko, N. A., N. E. Guselnikova, S. S. Vorobyeva \& N. F. Logacheva, 1993. Species composition of planktonic diatom algae of Lake Baikal and biology of dominant species. In Fifth Workshop on Diatom Algae: Diatom algae as indicators of the changes of climate and environment. Russian Academy of Sciences, Siberian Division, Irkutsk: 72-75.

Bradbury, J. P. \& K. V. Dieterich-Rurup, 1993. Holocene diatom paleolimnology of Elk Lake, Minnesota. In J. P. Bradbury \& W. E. Dean (eds), Elk Lake, Minnesota: evidence for rapid climate change in the North-Central United States. Geol. Soc. Amer. Spec. Paper No. 276. Geol. Soc. Amer., Boulder, Colorado: 215237.

Bradbury, J. P., Ye. V. Bezrukova, G. P. Chernyaeva, S. M. Colman, G. Khursevich, J. W. King \& Ye. E. Likoshway, 1994. A synthesis of post-glacial diatom records from Lake Baikal. J. Paleolim. 10: 213-252.

Carney, H., 1982. Algal dynamics and trophic interactions in the recent history of Frains Lake, Michigan. Ecology 63: 1814-1826.

Chernyaeva, G. P., 1970. Diatoms in the bottom sediments of northern Lake Baikal. In Bottom Deposits of Baikal. Academy of Sciences, Moscow: 144-160. (in Russian)

Conley, D. J. \& C. L. Schelske, 1993. Potential role of sponge spicules in influencing the silicon biogeochemistry of Florida lakes. Can. J. Fish. aquat. Sci. 50: 296-302.

Edgington, D. N., J. V. Klump, J. A. Robbins, Y. S. Kusner, V. D. Pampura \& I. V. Sandimirov, 1991. Sedimentation rates, residence times and radionuclide inventories in Lake Baikal from ${ }^{137} \mathrm{Cs}$ and ${ }^{210} \mathrm{~Pb}$ in sediment cores. Nature 350: 601-604.

Eggimen, D. W., F. T. Manheim \& P. R. Betzer, 1980. Dissolution and analysis of amorphous silica in marine sediments. J. sed. Petrol. 50: 215-225.

Flower, R. J., 1993. A taxonomic re-evaluation of endemic Cyclotella taxa in Lake Baikal, Siberia. Nova Hedwigia Beih. 106: 203220.

Foged, N., 1993. Some diatoms from Siberia especially from Lake Baikal. Diatom Research 8: 231-279.

Fritz, S. C., S. Juggins, R. W. Battarbee \& D. R. Engstrom, 1991. Reconstruction of past changes in salinity and climate using a diatom-based transfer function. Nature 352: 706-708.
Galazii, G., 1991. Lake Baikal reprieved. Endeavour, New Series 15: $13-17$.

Genkal, S. I. \& G. I. Popovskaya, 1991. New data on the frustule morphology of Aulacoseira islandica (Bacillariophyta). Diatom Research 6: 255-266.

Granina, L. Z., M. A. Grachev, E. B. Karabanov, V. M. Kuptsov, M. K. Shimaraeva \& D. F. Williams, 1993. Accumulation of biogenic silica in bottom sediments of Baikal. Russian Geology and Geophysics 34: 126-135.

Khotinskiy, N. A., 1984. Holocene climatic change. In Velichko, A. A. (ed.), Late Quaternary Environments of the Soviet Union. University of Minnesota Press, Minneapolis: 305-309.

Khursevich, G. K., 1989. Species Atlas. Stephanodiscus and Cyclostephanos (Bacillariophyta) from Upper Cenozoic sediments, USSR. Science and Techniques, Minsk, $86 \mathrm{pp}, 80 \mathrm{pl}$. (in Russian)

Kociolek, J. P. \& E. F. Stoermer, 1988. Taxonomy and systematic position of the Gomphoneis quadripunctata species complex. Diatom Research 3: 95-108.

Kozhov, M. M., 1963. Lake Baikal and its Life. Dr W. Junk Publishers, The Hague, 344 pp.

Kozhova, O. M., N. A. Shastina \& G. S. Kaplina, 1982. Size characteristics of Melosira islandica ssp. helvetica $\mathrm{O}$. Müll. from Lake Baikal. Hydrobiological J, 18: 6-10.

Kuzmin, M. I., D. F. Williams, N. A. Logachev, S. Colman, B. N. Khakhaev, T. Kawai, P. Hearn, Sh. Horie, L. A. Pevzner, A. A. Bukharov \& V. A. Fialkov, 1993. The Baikal Drilling Project: Scientific objectives and recent results. Russian Geology and Geophysics 34: 3-11.

Lake Baikal Paleoclimate Project Members, 1992. Initial results of U.S.-Soviet paleoclimate study of Lake Baikal. EOS, Trans. am. geophys. Union 73: 457-462.

Leinen, M., 1977. A normative calculation technique for determining opal in deep-sea sediments. Geoch. Cosmoch. Acta 41: 671-676.

Likhoshway, Ye., T. Nikiteeva, G. Pomazkina \& Ye. Meleshko, 1993. Fossil diatom algae of Lake Baikal. In Fifth Workshop on Diatom Algae: Diatom algae as indicators of the changes of climate and environment. Russian Academy of Sciences, Siberian Division, Irkutsk: 95-98.

Lorefice, G. J. \& M. Munawar, 1974. The abundance of diatoms in the southwestern nearshore region of Lake Ontario during the spring thermal bar period. Proc. 17th Conf. Great Lakes Res. 1974: 619-628.

Lund, J. W. G., 1966. The role of the turbulence in the seasonal cycle of some freshwater species of Melosira. Bot. Zh. 51: 176-187. (in Russian)

Lydolph, P. E., 1977. Climates of the Soviet Union. World Survey of Climatology; Vol. 7. Elsevier Scientific Pub. Co., Amsterdam, $443 \mathrm{pp}$.

Maatela, P., J. Paasivirta, M. A. Grachev \& E. B. Karabanov, 1990. Organic chlorine compounds in lake sediments. V. Bottom of Baikal near a pulp mill. Chemosphere 21: 1381-1384.

Makarova, I. V. \& G. V. Pomazkina, 1992. Stephanodiscus inconspicuus sp. nov. (Bacillariophyta). Algologia 2: 84-86. (in Russian)

Mortlock, R. A. \& P. N. Froelich, 1989. A simple method for the rapid determination of biogenic:opal in pelagic marine sediments. Deep Sea Res. 36: 1415-1426.

Peck, J. A., J. W. King, S. M. Colman \& V. A. Kravchinsky, 1994. A rock-magnetic record from Lake Baikal, Siberia: Evidence for Late Quaternary climate change. Earth Plan. Sci. Lett. 122: 221-238.

Pilskaln, C. H. \& J. Paduan, 1992. Laboratory techniques for the handling and geochemical analysis of water column particulate 
and surface sediment samples. MBARI Tech. Rept. No. 92-9, 22 pp.

Popovskaya, G. I., 1991. Phytoplankton of Lake Baikal and its longterm changes (1958-1990). Dissertation Abstract: Academy of Sciences, Siberian Division, Central Siberian Botanical Garden, Novosibirsk, 32 pp. (in Russian)

Popovskaya, G., 1993. Planktonic diatom algae of Lake Baikal and their long-term monitoring. In Fifth Workshop on Diatom Algae: Diatom algae as indicators of the changes of climate and environment. Russian Academy of Sciences, Siberian Division, Irkutsk: 114-116.

Riasanovsky, N. V., 1984. A History of Russia, 4th Ed. Oxford University Press, New York, $695 \mathrm{pp}$.

Shimaraev, M. N., N. G. Granin \& A. A. Zhdanov, 1993. Deep ventilation of Lake Baikal waters due to spring thermal bars. Limnol. Oceanogr. 38: 1068-1072.

Skvortzow, B. W., 1937. Bottom diatoms from Olhon Gate of Baikal Lake, Siberia. Philipp. J. Sci. 62: 293-377.

Skvortzow, B. W. \& C. I. Meyer, 1928. A contribution to the diatoms of Baikal Lake. Proc. Sungaree River Biological Station. 1: 1-55.

Smol, J. P., 1988. Paleoclimate proxy data from freshwater arctic diatoms. Verh. int. Ver. Limnol. 23: 837-844.

Stoermer, E. F. \& J. J. Yang, 1969. Plankton diatom assemblages in Lake Michigan. Univ. of Michigan, Ann Arbor, Michigan, Great Lakes Research Division Special Rep. No. 47, 168 pp.

Stoermer, E. F., R. G. Kreis \& L. Sicko-Goad, 1981. A systematic, quantitative, and ecological comparison of Melosira islandica O. Muill. with $M$. granulata (Ehr.) Ralfs from the Laurentian Great Lakes. J. Great Lakes Res. 7: 345-356.

Stoermer, E. F., J. A. Wolin, C. L. Schelske \& D. J. Conley, 1985a. Postsettlement diatom succession in the Bay of Quinte, Lake Ontario. Can. J. Fish. aquat. Sci. 42: 754-767.

\section{Note added in proof}

\section{Stephanodiscus inconspicuus Makarova et Pomazkina has recently been transferred to the new genus Cra- teriportula (Flower \& Håkansson, 1994), as C. incon- spicua (Mak. et Pom.) Flower et Håkansson.}

Flower, R.J. and Håkansson, H. 1994. Crateriportula gen. nov., a new genus with close affinities to the genus Stephanodiscus. Diatom Research 9: 259-264.
Stoermer, E. F., J. A. Wolin, C. L. Schelske \& D. J. Conley, 1985b. An assessment of ecological changes during the recent history of Lake Ontario based on siliceous algal microfossils preserved in the sediments. J. Phycol. 21: 257 276 .

Stoermer, E. F, J. P. Kociolek, C. L. Schelske \& D. J. Conley, $1985 \mathrm{c}$. Siliceous microfossil succession in the recent history of Lake Superior. Proc. Acad. nat. Sci. Philad. 137: 106-118.

Stoermer E. F., Q. Yu-zao \& T. B. Ladewski, 1986. A quantitative investigation of shape variation in Didymosphenia (Lyngbye) M. Schmidt (Bacillariophyta). Phycologia 25: 494-502.

Stoermer, E. F., C. L. Schelske \& J. A. Wolin, 1990. Siliceous microfossil succession in the sediments of McLeod Bay, Great Slave Lake, Northwest Territories. Can. J. Fish, aquat. Sci. 47: 1865-1874.

Stoermer, E. F., J. A. Wolin \& C. L. Schelske, 1993. Paleolimnological comparison of the Laurentian Great Lakes based on diatoms. Limnol. Oceanogr. 38: 1311-1316.

Stoermer, E.F., M. B. Edlund, C. H. Pilskaln \& C. L. Schelske, 1995. Siliceous microfossil distribution in the surficial sediments of Lake Baikal. J. Paleolim. (in press).

Weiss, R. F., E. C. Carmack \& V. M. Koropalov, 1991. Deep-water renewal and biological production in Lake Baikal. Nature 349: 665-669.

Wilkinson, L , 1989. SYSTAT: The System for Statistics. SYSTAT, Inc., Evanston, IL, 638 pp.

Williams, D. F., L. Qui, E. Karabanov \& A. Gvozdkov, 1993. Geochemical indicators of productivity and sources of organic matter in surficial sediments of Lake Baikal. Russian Geology and Geophysics 34: 111-125. 